Business and Economics Research Journal

Volume 7 Number 32016

pp. $89-110$

ISSN: $1309-2448$

DOI Number: 10.20409/berj.2016321810

\title{
Kâr Yönetimi, Bağımsız Denetim Görüşü ve Denetim Firması Değişimi Arasındaki İlişskiler: Borsa İstanbul İmalat Sektörüne Yönelik Bir Araştırma
}

\begin{abstract}
Murat Ocak $^{\mathrm{a}}$
Öz: Bu çalışmada ilk olarak tahakkuk/işlem esaslı kâr yönetimi ve bağımsız denetim görüşü arasındaki ilişsi araştırılmıştır. ikinci olarak geçmiş dönemde alınan olumlu görüş dışındaki görüşlerin mevcut dönemde denetim firması değişimine etkisi araştırılmıştır. Borsa istanbul imalat sektöründe yer alan 1121 işletme'yıl gözlem kullanılmıştır. Sonuçlar, tahakkuk esaslı kâr yönetiminin göstergesi olan ihtiyari tahakkukların işaretli/mutlak değerleri ile olumlu görüş dışındaki görüş arasında pozitif ve anlamlı ilişki olduğunu göstermektedir. İşlem esaslı kâr yönetiminin göstergesi olan anormal üretim maliyeti ve anormal faaliyet giderlerinin toplamı ile olumlu görüş dışında bir görüş alma durumu arasında anlamlı bir ilişkiye rastlanmamıştır. Geçmiş dönemde olumlu görüş dışında bir görüş alma ile mevcut dönemde denetim firması değişimi arasında pozitif ve anlamlı ilişki tespit edilmişsir. Ayrıca 2013 yılındaki denetim firması değişikliklerinde zorunlu rotasyon uygulamasının etkili olduğu ve işletmelerin denetim firmalarını değiş̧irdiği görülmektedir.
\end{abstract}

Anahtar Sözcükler: Bağımsız Denetim Görüşü, Tahakkuk Esaslı Kâr Yönetimi, İşlem Esaslı Kâr Yönetimi, Denetim Firması Değişimi, Borsa İstanbul

JEL Sınıflandırması: M40, M41, M42

\section{The Relationships Among Earnings Management, Independent Audit Opinion and Audit Firm Switch: A Research on Manufacturing Industry at Borsa İstanbul}

\begin{abstract}
In this paper, firstly the relationship between accruals/real transactions based earnings management and audit opinion is investigated. Secondly, the effect of prior modified audit opinion on audit firm switch is investigated. 1121 firm'year observations on Borsa Istanbul Manufacturing Industry are used. The results show that there is positive and significant relationship between the signed/absolute value of discretionary accruals and modified audit opinion. There is no relationship between the total amount of the abnormal production cost/abnormal operating expenses and modified audit opinion. A positive and significant relationship between prior modified auditor opinion and audit firm switch is determined. Audit rotation regulation has an effect on the audit firm switch in 2013 and companies change their audit firms.
\end{abstract}

Keywords: Independent Audit Opinion, Accruals Based Earnings Management, Real Activities Based Earnings Management, Audit Firm Switch, Borsa İstanbul

JEL Classification: M40, M41, M42

\footnotetext{
Assist. Prof. Dr., Trakya University Uzunköprü School of Applied Sciences, Department of Business Information Management, Edirne, Turkiye, muratocak@trakya.edu.tr
} 


\section{Giriş}

Bağımsız denetimin amacı, finansal tablo kullanıcılarına bir bütün olarak finansal tabloların hata veya hile kaynaklı önemli bir yanlışlık içermediğine ilişkin makul bir güvence vermektir. Bağımsız denetim sonucunda finansal tabloların tüm önemli yönleriyle gerçeğe uygun bir biçimde sunulup sunulmadığına veya doğru ve gerçeğe uygun bir görünüm sağlayıp sağlamadığına ilişkin bir görüş bildirilmektedir. Bağımsız denetim sonucu elde edilen görüş 4 farklı şekildedir. Bunlar, (i) olumlu görüş, (ii) olumsuz görüş, (iii) şartlı görüş, (iv) görüş bildirmekten kaçınmadır. Finansal tablolar bir bütün olarak gerçeğe uygun bir şekilde sunulmuşsa olumlu görüş; bir bütün olarak finansal tabloların önemli yanlışlık içermesi veya bir bütün olarak finansal tabloların önemli yanlışlık içermediği sonucuna varmak için yeterli ve uygun denetim kanıtı elde edilememesi durumunda olumlu görüş dışında bir görüş (olumsuz görüş, şartlı görüş, görüş bildirmekten kaçınma) verilmektedir (Kamu Gözetimi Muhasebe ve Denetim Standartları Kurumu, BDS 200; BDS 700; BDS 705).

Kâr yönetimi literatürde iki başlık altında toplanmaktadır. Genel kabul görmüş muhasebe ilkeleri, standartlar ve yasal düzenlemeler çerçevesinde tahakkukların kullanılması yoluyla kârın istenilen seviyeye getirilmesi "tahakkuk esaslı kâr yönetimi" olarak adlandırılmaktadır. "İşlem esaslı kâr yönetimi" ise tahakkuk esaslı kâr yönetimi uygulamalarının aksine, muhasebeye ve finansal tablolara konu olacak ekonomik faaliyetlerin ve işlemlerin zamanlamasını ayarlayarak kârın istenilen seviyeye getirildikten sonra finansal tablo kullanıcılarına sunulmasıdır. Her iki uygulama da finansal tabloların kalitesizliğine işaret etmektedir. Bu tür uygulamalara başvurulmuş finansal tablolar, gerçeğe uygun sunumdan uzaklaşmakta, işletme hakkında doğru olmayan bilgiler verip işletmenin taraflarını verecekleri kararlarda yanıltmaktadır. Sonuç olarak, işletmeler tahakkukları kullanarak veya işlemleri ayarlayarak kârı ne kadar yönettiyse finansal tablolarına olumlu görüş dışında görüş alma olasııı̆ının o kadar yüksek olması beklenmektedir. Tahakkuk esaslı kâr yönetimi muhasebe verileri ve nihai olarak finansal tablolar üzerine gerçekleştirildiğinden etkin bağımsız denetimin bunu tespit edip finansal tablolara olumlu görüş dışında bir görüş vermesi olasıdır. İşlem esaslı kâr yönetimi muhasebeye konu olmadan önce gerçekleştiğinden dolayı denetim ne kadar etkin olursa olsun bunu ortaya çıkarması olası olmayabilir.

İşletmeler ister kârlarını yönettikleri için ister başka nedenlerle olsun finansal tablolarına olumlu görüş dışında görüş alabilir. Finansal tablolara alınan olumlu görüş dışındaki görüşler işletmeyi bulunduğu sektörde, ticari ilişkilerinde olumsuz etkileyebileceğinden işletmelerin geçmiş dönemde olumlu görüş dışında bir görüş aldıklarından dolayı denetim firmalarını değiştirme eğiliminde oldukları yapılmış olan çalışmalarda vurgulanmaktadır. (Chow ve Rice, 1982; Craswell, 1988 ; Vanstraelen, 2003 ; Chan, Lin ve Mo, 2006; Hudaib ve Cooke, 2005).

Borsa İstanbul'daki işletme verileri kullanılarak, kâr yönetimi konusu ile ilgili ülkemizde yapılmış olan çalışmalar; tahakkuk esaslı kâr yönetiminin tespiti (Acar, 2011; Aren, 2003; Ayarlıoğlu 2007), kurumsal yönetişimin tahakkuk esaslı kâr yönetimini engelleyici etkisi (Adıgüzel, 2012; Karaibrahimoğlu, 2010; Önder, 2012; Varan, 2012; Yaşar, 2011; Ocak, 2013), halka arz ve tahakkuk esaslı kâr yönetimi (Yükseltürk, 2006), Uluslararası Finansal Raporlama Standartları ve tahakkuk esaslı kâr yönetimi (Durak, 2010; Ertan, 2011; Karabayır, 2012; Özden, 2013), etik ve kâr yönetimi (Kabadayı, 2010; Özcan, 2007), bağımsız denetim ve tahakkuk esaslı kâr yönetimi (Karacaer ve Özek, 2010) başlıkları altında toplanmaktadır. Curuk ve Yasar (2014) tarafından yapılan tahakkuk esaslı kâr yönetimi ve finansal tablolara şartlı ve olumsuz görüş alma arasındaki ilişkiye yönelik 2003-2007 yıllarını ve 290 işletme'yıl gözlemi kapsayan imalat sektörüne yönelik bir çalışma mevcuttur.

Bu çalışmanın ilk amacı tahakkuk ve işlem esaslı kâr yönetiminin finansal tablolara alınan olumlu görüş dışındaki görüşler üzerindeki etkisini ortaya koymaktır. Çalışmada kâr yönetimi hem tahakkuk esası hem de işlem esaslı boyutu ile ele alındığından Curuk ve Yasar'ın (2014) yapmış olduğu çalışmadan farklılaşmaktadır. Bu çalışma işlem esaslı kâr yönetimi ile denetim görüşü arasındaki ilişkiye yönelik bulgular sunup literatüre katkı sağlamayı amaçlamaktadır. 
Çalışmanın ikinci amacı geçmiş dönemde alınmış olan olumlu görüş dışındaki bağımsız denetim görüşünün mevcut dönemde denetim firması değişikliğine etkisini tespit etmektir. Bu konuda uluslararası literatürde hatırı sayılır düzeyde çalışma olmasına karşılık Türkiye'de Yaşar (2015) tarafından yapılan ve sadece olumsuz denetim görüşünün bağımsız denetim firması değişikliği üzerindeki etkisine yönelik bulgulara rastlanmaktadır. Arioğlu ve Tuan (2015) ise denetim firması değişiminin piyasa tepkisine etkisini araştırmıştır. Bu çalışma sadece denetim görüşü değil, denetim firması ile ilişki süresi, işletmenin büyüklüğündeki değişim, sahiplik yapısındaki değişim, yıl gibi faktörlerin denetim firması değişikliğine etkisine yönelik bulgular da sunmaktadır. Böylece, Türkiye'ye ilişkin bulgular elde edilip ulusal literatürdeki boşluğun kısmen doldurulacağı düşünülmektedir.

Çalışma, tahakkukların işletmeler tarafından yönetilmesinin ve işletmelerin finansal tablolara konu olacak işlemleri yönetmesinin denetim firmaları tarafından finansal tablolara verilecek olan bağımsız denetim görüşünde etkili olup olmadığına, finansal tablolara verilen olumlu dışındaki bağımsız denetim görüşlerinin ise denetim firması değişiminde etkili olup olmadığına yönelik bir çerçeve sunmaktadır. Ayrıca işletmelerin finansal zorlukta olmasının denetim görüşüne etkisi, bağımsız denetim firması ile iş ilişki süresinin bağımsız denetim görüşüne ve denetim firması değişimine etkisine yönelik Borsa İstanbul'da işlem gören imalat sektöründeki işletmeler açısından genel eğilimi ortaya koymaktadır.

Aşağıda çalışmanın ikinci bölümünde araştırma konularına ilişkin literatür ve kurulan hipotezler ele alınmıştır. Çalışmanın üçüncü bölümünde veriler, veri toplama süreci, değişkenlerin nasıl ölçüldüŭü, araştırma modelleri açıklanmıştır. Son bölümde analiz sonuçları değerlendirilmiştir.

\section{Konuya Illişkin Literatür ve Hipotezler}

Aşağıda konuya ilişkin tahakkuk esaslı ve işlem esaslı kâr yönetimi ile bağımsız denetim görüşü arasındaki ilişkiye yönelik literatür ve kurulan hipotezler ele alınmıştır.

\subsection{Kâr Yönetimi ve Bağımsız Denetim Görüşü Arasındaki iliş̧i}

Kâr yönetimi konusu iki başlık altında toplandığından ilk araştırma konumuza ilişkin çalışmalar da iki başık altında toplanmaktadır.

\subsubsection{Tahakkuk Esaslı Kâr Yönetimi ve Olumlu Görüş Dışında Görüş Alma Arasındaki ilişki}

Bartov, Gul ve Tsui (2000), 166 işletme üzerine yapmış oldukları çalışmada Jones Modeli'ne (1991) ve Değiştirilmiş Jones Modeli (Dechow, Sloan ve Sweeney, 1995)'ne göre işletmelerin başvurdukları ihtiyari tahakkuk tutarlarını tespit etmiştir. Bu tutarların mutlak değerleri ile finansal tablolara şartlı görüş alma durumu arasında pozitif anlamlı ilişki tespit etmişlerdir. Elde edilen bulgu ile işletmelerin tahakkukları ayarlayarak kârı yönetmesinin, finansal tablolara şartlı görüş almaya neden olduğu sonucuna varılmıştır. Sengupta ve Shen (2007), 2000-2004 yılları arasında 9477 işletme'yıl gözlem üzerine yapmış oldukları çalışmada, işletmenin sürekliliğinin tehlikeye düşmesi nedeniyle şartlı görüş alma durumu ile ihtiyari tahakkukların işaretli ve mutlak değerleri arasında pozitif anlamlı ilişkiye rastlamışlardır. Araştırmacılar, işletmeler ne kadar ihtiyari tahakkuka başvurmuşsa finansal tablolarına şartlı görüş alma olasılığının o kadar artacağı sonucuna varmışlardır.

Butler, Leone ve Willenborg (2004), 2236 işletme'yıl gözlem üzerine yapmış oldukları çalışmada, Jones Modeli'ne göre tespit ettikleri ihtiyari tahakkukların mutlak değerleri ile olumlu görüş dışında görüşlerden herhangi birini alma durumu arasında pozitif anlamlı ilişkiye rastlamışlardır. Olumlu görüş dışında herhangi bir görüş alma durumunu; işletmenin sürekliliğinin tehlikeye düşmesi nedeniyle şartlı görüş alma ve olumlu görüş dışındaki görüşlerin diğerlerinden birini alma diye ikiye ayırdığı zaman, sadece sürekliliğin tehlikeye düşmesi nedeniyle şartlı görüş alma durumu ile ihtiyari tahakkukların mutlak değerleri arasında pozitif anlamlı ilişkiye rastlamışlardır. Yazarlara göre bunun muhtemel nedeni, sürekliliği tehlikeye düşen işletmelerin finansal sıkıntıda olmasıdır. Bu işletmeler, likidite kısıtı ile karşı karşıya kalmakta, üstesinden gelebilmek için nakit dışı çalışma sermayesi kalemlerini azaltma yoluna gitmekte veya alacaklar, stoklar gibi kalemler için büyük miktarlarda karşılık ayırma durumunda kalmaktadırlar. Bu durum, büyük 
miktarlarda negatif yönlü tahakkuka sebep olmaktadır. Tahakkuk esaslı kâr yönetiminin tespitine ilişkin modeller bu işletmelere uygulandığı zaman, büyük miktarlardaki negatif yönlü tahakkuklardan dolayı işletmelerin negatif yönlü intiyari tahakkuka başvurduğu ortaya çıkmaktadır. Aslında, bu işletmeler negatif yönlü ihtiyari tahakkuka başvurmaları nedeni ile değil, finansal sıkıntıya düştüklerinden dolayı şartlı görüş almaktadır. Benzer ve destekleyen bulgulara daha sonra Herbohn ve Ragunathan (2008)'ın Avusturalya'da yapmış oldukları çalışmada rastlanmıştır.

Butler vd. (2004)'lerinin savunduklarına benzer bulgular elde eden fakat bir noktada aksini söyleyen çalışma da literatürde mevcuttur. Ajona, Dallo ve Alegría (2008); 1993-2002 yılları arasında 1261 işletme'yıl gözlem üzerine yapmış olduğu çalışmada, olumlu görüş dışında görüşlerden herhangi birini almış işletmeleri iki gruba ayırmıştır. Bunlar, (i) işletmenin sürekliliğinin tehlikeye düşmesi nedeniyle şartlı görüş almış, (ii) genel kabul görmüş muhasebe ilkelerinin ihlali, denetim kapsamının sınırlaması gibi nedenlerle olumlu görüş dışında diğer görüşleri almış işletmelerdir. Shivakumar (1996)'ın nakit bazlı modeline göre tespit edilen ihtiyari tahakkukların işaretli değerleri ile genel kabul görmüş muhasebe ilkelerinin ihlali, kapsam sınırlaması gibi nedenlerle olumlu görüş dışında diğer görüşleri alma durumu arasında pozitif anlamlı ilişki tespit edilirken; ihtiyari tahakkukların işaretli değerleri ile işletmenin sürekliliğinin tehlikeye düşmesi nedeniyle şartlı görüş alma arasında negatif anlamlı ilişkiye rastlamışlardır. Yazarlar, ikinci grupta yer alan işletmelerin intiyari tahakkuka başvurmalarından dolayı finansal tablolarına olumlu görüş dışında diğer görüşlerden birini aldıklarını; fakat ilk grupta yer alan işletmelerin Butler vd. (2004)'nin savunduğunun aksine finansal sıkıntıda olduklarından dolayı değil, bağımsız denetçilerin muhafazakâr politikalarının bir sonucu olarak şartlı görüş aldıklarını savunmaktadırlar.

Gajevszky (2014), Romanya'da 2012 yılında 60 işletme üzerine yapmış olduğu çalışmada, işletmelerin ihtiyari tahakkuk tutarları ile finansal tablolarına olumlu görüş dışında bir görüş alma durumu arasında negatif anlamlı ilişkiye rastlamıştır. Tsipouridou ve Spathis (2014), 2005-2011 yılları arasında 1479 işletme'yıl gözlem üzerine yapmış oldukları çalışmada, Değiştirilmiş Jones Modeli'ne göre tespit ettikleri intiyari tahakkukların işaretli değerleri ile bağımsı denetim görüşü arasında anlamlı bir ilişkiye rastlamamışlardır. Curuk ve Yasar (2014) tarafından 290 işletme'yıl gözlem üzerine yapılan çalışmada da şartlı ve olumsuz görüş alma durumu ile Değiştirilmiş Jones Modeli'ne göre tespit ettikleri ihtiyari tahakkukların işaretli değerleri arasında anlamlı bir ilişkiye rastlamamışlardır.

Omid (2015), Tahran Borsası'nda 2818 işletme'yıl veri üzerine yapmış olduğu çalışmada, işletmelerin ihtiyari tahakkuklarını tespit ederken Kazsnik'in Nakit Akışı Eşlemeli Modeli'ni (1999) kullanmıştır. İşlem esaslı kâr yönetimini tespit ederken Roychowdhury (2006) modelini kullanmıştır. İşletmeler ne kadar fazla ihtiyari tahakkuka başvurmuşsa finansal tablolarına şartlı görüş alma olasılı̆̆ı artarken, Roychowdhury Modeli'ne (2006) göre tespit ettiği işlem esaslı kâr yönetimi büyüklükleri ile şartlı görüş alma arasında anlamlı bir ilişkiye rastlamamıştır.

Olumlu görüş dışındaki görüşler şartlı görüş, olumsuz görüş ve görüş bildirmekten kaçınma olmakla birlikte, bazı yazarlar sadece şartlı görüş alma durumu ile intiyari tahakkukların işaretli/mutlak değerleri arasındaki ilişki araştırmaya yönelik çalışmalar yaparken (Bartov vd.,2000; Sengupta ve Shen, 2007), bazıları olumlu görüş dışındaki birden fazla görüş çeşidini bir arada kullanarak ihtiyari tahakkukların işaretli/mutlak değerlerinin bu görüşler üzerindeki etkisini tespit etmeye yönelik analizler yapmıştır (Butler vd.,2004; Ajona vd., 2008). Olumlu görüş dışındaki görüşlerin hepsi işletmelerde bir şeylerin yolunda gitmediğinin göstergesidir. Bu çalışmada, Butler vd. (2004) takip edilerek olumlu görüş dışındaki görüşlerden sadece biri üzerine yoğunlaşılmayıp, ilk modelde bağımlı değişken olumlu görüş dışındaki görüşler (Şartlı Görüş, Görüş Bildirmekten Kaçınma ve Olumsuz Görüş) ve olumlu görüş olmak üzere ikiye ayrılarak kullanmıştır.

Bazı yazarlar (Sengupta ve Shen, 2007; Tsipouridou ve Spathis, 2014; Curuk ve Yasar, 2014) tahakkuk esaslı kâr yönetiminin göstergesi olan ihtiyari tahakkukların bağımsız denetim görüşü üzerindeki etkisini tespit ederken, modellerinde ihtiyari tahakkukların işaretli değerlerini, bazı yazarlar (Butler vd., 2004; Sengupta ve Shen, 2007; Bartov vd., 2000) ise ihtiyari tahakkukların mutlak değerlerini kullanmıştır. 
İhtiyari tahakkukların işareti kârın ne yönde yönetildiğinin göstergesidir. Modeller sonucu elde edilen ihtiyari tahakkuk negatif değerde ise kârı azaltıcı ihtiyari tahakkuka başvurulduğunun, pozitif ise kârı arttırıcı intiyari tahakkuka başvurulduğunun göstergesidir. Tahakkuk esaslı kâr yönetiminin finansal tablolara olumlu görüş dışında görüş alma üzerindeki etkisinin tespit edildiği modelde (1. Model), ihtiyari tahakkukların işaretli yönlerinin (negatif ve pozitif) kullanılması ile elde edilen sonuçlarda, katsayının yönü pozitif ve anlamlı ise işletmelerin pozitif yönlü ihtiyari tahakkuka başvurmalarından, elde edilen katsayının yönü negatif ve anlamlı ise negatif yönlü intiyari tahakkuka başvurmalarından dolayı finansal tablolarına olumlu görüş dışında bir görüş aldıklarının göstergesi olacaktır. Bu çalışmanın amaçlarından biri işletmelerin hangi yönde ihtiyari tahakkuka başvurduğundan dolayı finansal tablolarına olumlu görüş dışında bir görüş alma olasılığının arttığını belirlemektir. Bu yüzden aşağıda ampirik olarak izah edilen birinci model ilk olarak ihtiyari tahakkukların işaretli yönleri ile çalıştırıımıştır. Bu bağlamda ilk hipotez;

$\mathbf{H}_{1 \mathrm{~A}}=$ ìhtiyari tahakkukların işaretli değerleri ile finansal tablolara olumlu görüş dışında görüş alma durumu arasında anlamlı bir ilişki mevcuttur.

Modellerinde ihtiyari tahakkukların mutlak değerlerini kullanan yazarlar da mevcuttur. ìntiyari tahakkukların mutlak değerlerinin kullanılması işletmelerin kârını ne yönde yönettiği değil ne miktarda yönettiği hususunda önemlilik arz etmektedir. İşletmeler ne kadar fazla miktarda ihtiyari tahakkuka başvurarak kârını yönetirse finansal tablolarına olumlu görüş dışında görüş alma olasılığı o kadar artabilir. Bu bağlamda diğer hipotez;

$\mathbf{H}_{1 \mathrm{~B}}=$ ìhtiyari tahakkukların mutlak değerleri ile finansal tablolara olumlu görüş dışında görüş alma durumu arasında pozitif ve anlamlı bir ilişki mevcuttur.

\subsection{2 İşlem Esaslı Kâr Yönetimi ve Olumlu Görüş Dışında Görüş Alma Arasındaki ilişski}

Graham, Harvey ve Rajgopal (2005); 401 üst düzey finans yöneticisi üzerine yapmış oldukları anket çalışmasında, yöneticilerin kârlılık hedeflerine ulaşmak amacı ile ihtiyari tahakkuka başvurarak kârı yönetmek yerine muhasebeye konu olacak ekonomik olayları tasarlayarak kârı yönetme eğiliminde olduğunu tespit etmişlerdir. Anketteki katılımcıların \%80'i, kârlıık hedeflerine ulaşmak amacı ile araştırmageliştirme; pazarlama harcamalarını isteğe bağlı olarak kısma eğilimindedir. Yazarlara göre bunun birkaç nedeni vardır. Bunlardan ilki; Enron ve WorldCom gibi skandallardan sonra tahakkuk esaslı kâr yönetimi uygulamalarının gün yüzüne çıkması ve yöneticilerin tahakkukları yönetmekten çok işlemleri tasarlayarak kârı yönetme eğiliminde olmasıdır. Bir diğer nedeni ise, her ne kadar işlem esaslı kâr yönetimi uygulamaları finansal tabloların doğru ve gerçeğe uygun sunumdan uzaklaşmasına neden olsa bile, işin normal akışı içerisinde kârlılık hedeflerine ulaşmak amacı ile yöneticilerin işlemleri tasarlayarak kârı yönetmesine bağımsız denetçilerin kolay bir şekilde itiraz etmesi mümkün değildir. Ayrıca, hiçbir yönetici işletmenin paydaşlarına kârlıık ile ilgili işlerin yolunda gittiğini vurgulamak amacı ile muhasebe kayıtlarında ve finansal tablolarında bağımsız denetim sonucu ortaya çıkabilecek olan tahakkuk esaslı kâr yönetimi uygulamalarına başvurmak istememektedir. Bunun yerine muhasebe kayıtlarında ve finansal tablolarda doğrudan ortaya çıkmayacak fakat etki edebilecek olan işlem esaslı kâr yönetimi uygulamalarına başvuracaktır.

Cohen, Dey ve Lys (2008) Sarbanes-Oxley Kanunu (SOX) ile gelen düzenlemelerle birlikte işletmelerin SOX'tan sonra ihtiyari tahakkuka başvurarak kârı yönetmek yerine muhasebeye konu olan işlemleri tasarlayarak kârı yönettiklerini gözlemlemişlerdir. Bu durumun nedeni olarak ise SOX ile birlikte gelen düzenlemelerin tahakkuk esaslı kâr yönetimi uygulamalarını engellemesi, fakat işlem esaslı kâr yönetiminde; kâr muhasebeye konu olmadan işlemler tasarlanarak yönetildiği için bunun bağımsız denetim, düzenleyici kuruluşlar, yönetim kurulu, denetim komitesi gibi birimler tarafından ortaya çıkarılmasının zor olması olarak görmektedir. Chi, Lisic ve Pevzner (2011) tarafından yapılan 2001-2008 yıllarını ve 925 işletme'yıl gözlemi kapsayan çalışmada, kaliteli bağımsız denetimin tahakkuk esaslı kâr yönetimi ve işlem esaslı kâr yönetimini engellemedeki rolü incelenmiştir. Araştırmacılar kaliteli bağımsız denetimin tahakkuk esaslı kâr yönetimi uygulamalarını tespit etmede ve engellemede etkili olduğunu, bu durumun ise işletmeleri tahakkuk esaslı kârı yönetmek yerine işlemleri tasarlayarak kârı yönetmeye yönlendirdiğini ortaya koymuşlardır. 
Literatürde Cohen vd. (2008) ve Graham vd. (2005)'nın savunduğu gibi işlem esaslı kâr yönetimin bağımsız denetim kuruluşları, düzenleyici kuruluşlar, yönetim kurulu, denetim komitesi gibi birimler tarafından tespit edilmesi ve ortaya çıkarılması oldukça zor olabilir. İşlem esaslı olarak kârın yönetilmesi, işlemler daha muhasebeye ve finansal tablolara konu olmadan gerçekleştirilmektedir. İşlem esaslı kâr yönetimi her ne kadar finansal tabloların doğru ve gerçeğe uygun sunumdan uzaklaşmasına neden olan uygulamalar olsa bile bu tür kâr yönetimi uygulamaları muhasebeye ve finansal tablolara konu olmadan önce gerçekleştirildiğinden bağımsız denetim kuruluşları tarafından tespit edilip işletmenin finansal tablolarına olumlu görüş dışında bir görüş verilmesi söz konusu olmayabilir. Bu bağlamda diğer hipotez;

$\mathbf{H}_{2}=$ İşlem esaslı kâr yönetimi ile finansal tablolara olumlu görüş dışında görüş alma durumu arasında anlamlı bir ilişki yoktur.

\subsection{Bağımsız Denetim Görüşü ve Denetim Firması Değişimi}

Chow ve Rice (1982)'e göre geçmiş dönemde finansal tablolara şartlı görüş almak işletmenin hisse değerini etkileyeceğinden mevcut dönemde olumlu görüş alma olasılığını arttırmak için işletmeler denetim firmasını değiştirme eğilimindedir. Craswell (1988)'e göre, şartlı görüş almanın yöneticiler açısından maliyeti vardır. Yöneticilerin ücret paketleri içinde sermayeye dayalı ödemeler bulunabilir. Şartlı görüş işletmenin hisselerinin değerini etkileyeceğinden kârlılık da buna bağlı olarak azalacak ve yöneticilerin sermayeye dayalı ödemeleri de olumsuz yönde etkilenecektir. Bu yüzden işletmeler denetim firması değiştirme eğiliminde olmaktadır. Chow ve Rice (1982), Craswell (1988), Vanstraelen (2003), Chan, Lin ve Mo (2006), Hudaib ve Cooke (2005); farklı ülkelerdeki işletme verilerini kullanarak geçmiş dönemde şartlı görüş almanın mevcut dönemde denetim firması değişikliğine neden olduğunu tespit etmişlerdir.

Chan vd. (2006), şartlı görüş aldıktan sonra gerçekleşen denetim firması değişikliğinin yönünün yabancı denetim firmalarından yerel denetim firmalarına doğru olduğunu tespit etmişlerdir. Chow ve Rice (1982) geçmiş dönemde şartlı görüş alıp denetim firması değiştiren ve değiştirmeyen işletmeleri kıyasladığı zaman; geçmişte şartlı görüş alan ve denetim firması değişikliğine giden işletmelerin mevcut dönemde olumlu görüş aldığı veya olumlu görüş almak için büyük denetim firmaları dışında bir denetim firması ile çalışmaya başladığı yönünde bir bulguya rastlamamışlardır.

Hudaib ve Cooke (2005), geçmiş dönemde şartlı görüş alan fakat finansal sıkıntıda olmayan ve üst düzey yöneticisini değiştiren işletmelerin, geçmiş dönemde şartlı görüş alan aynı zamanda finansal sıkıntıda olan ve üst düzey yöneticisini değiştirmeyen işletmelere göre denetim firması değiştirme yönünde daha fazla eğilime sahip olduğunu tespit etmiştir.

Lennox (2000), 1988-1994 yılları arasında İngiltere'de borsaya kote olan toplamda 5441 işletme'yıl veri üzerine yapmış olduğu çalışmada geçmiş dönemde olumlu görüş dışında bir görüş almanın mevcut dönemde denetim firması değişikliğine neden olduğunu, denetim firması değiştikten sonra yeni denetim firmasının, geçmiş dönemdeki denetim görüşünün aksine görüş verdiğini ortaya koymuştur. Bu bağlamda yazara göre, bağımsız denetim görüş alışverişi mevcuttur ve işletmeler geçmiş dönemde olumlu görüş dışında bir görüş aldığında denetim firmasını değiştirerek olumlu görüş alma eğilimindedir.

Davidson III, Jiraporn, DaDalt (2006), 1993-1997 yılları arasında 319 işletme üzerine yapmış olduğu çalışmada, geçmiş dönemde olumlu görüş dışında görüş almış işletmelerin mevcut dönemde denetim firması değişikliğine gittiğini ve yeni dönemdeki denetim firmasının 6 büyük denetim firmasından biri olmadığını tespit etmiştir. Bunun nedeni olarak ise, küçük bir denetim firmasına geçip olumlu görüş alma olasılığını arttırma olarak görmektedir.

Salleh ve Jasmani (2014), Malezya'da 2003-2012 yıllarını ve 156 işletmeyi kapsayan çalışmalarında bağımsız denetim görüşünün denetim firması değişikliğine gitmede önemli bir unsur olmadığını tespit etmişlerdir.

Görüldüğü üzere geçmiş dönemde alınan bağımsız denetim görüşünün mevcut dönemde denetim firması değişimine etkisine yönelik çalışmalarda da test değişkeni olarak kullanılan geçmiş dönem bağımsız denetim görüşünü bazı yazarlar (Craswell, 1988; Chow ve Rice, 1982) şartlı görüş ve olumlu görüş, bazı 
yazarlar da (Lennox, 2000; Davidson III vd., 2006) olumlu görüş dışındaki görüşler ve olumlu görüş diye sınıflandırarak analizler gerçekleştirilmiştir. Bu çalışmada Lennox (2000) ve Davidson III (2006)'u takip edilmiştir. Onların elde etmiş olduğu bulgulardan yola çıkarak oluşturulan dördüncü hipotez;

$\mathbf{H}_{3}$ : Geçmiş dönemde olumlu görüş dışında bir görüş alma durumu ile mevcut dönemde denetim firması değişikliği arasında pozitif ve anlamlı ilişki vardır.

\section{Araştırmanın Yöntemi}

Aşağıda veriler, veri toplama süreci, araştırmanın modelleri, bağımlı değişkenler, test değişkenleri, kontrol değişkenleri detaylı bir biçimde açıklanmıştır.

\subsection{Veriler ve Veri Toplama Süreci}

Çalışmada 2006-2013 yılları arasında Borsa İstanbul Tüm Endeksinde (XUTUM) imalat sanayi sektöründe faaliyette bulunan işletmeler kullanılmıştır. Bu örneklemin kullanılmasının nedeni Borsa İstanbul'daki işletmelerin bağımsız denetime gerekli önemi vermesi ve kote olan işletmelerin bağımsız denetim kuruluşları tarafından ciddi bir şekilde denetime tabi olmasıdır. Böylelikle elde edilen bulgular bağımsız denetim görüşü, kâr yönetimi, denetim firması değişimi arasındaki ilişkiler yönünden dikkate değer bir gösterge olacaktır. Bulgular sunulmadan önce yapılan incelemede teknoloji, ticaret gibi ana sektörler örnekleme dahil edildiğinde bu sektörlerde imalat sektörüne oranla olumlu görüş dışında bir görüş alma durumu ile sıklıkla karşılaşılmadığı gözlemlenmiştir. Bu yüzden teknoloji, ticaret gibi sektörler çalışmadan çıkarılmıştır. Ayrıca finansal kuruluşlarda Kothari, Leone ve Wasley (2005)'in performans eşlemeli modeli (2005) ve Roychowdhury Modeli (2006) modeli uygulanmamaktadır. Bu yüzden finans kuruluşları örneklemden çıkarılmıştır. 2013 yılı itibari ile toplamda 196 işletme imalat sanayinde faaliyette bulunmaktadır. 8 yıl itibari ile (196 işletme x 8 yıl) 1568 işletme'yıl gözlem mevcuttur. Bağımlı, test ve kontrol değişkenlerine ilişkin verileri toplarken toplamda 447 işletme'yıl gözlem kayıptır. Çünkü ihtiyari tahakkukları, işlem esaslı kâr yönetimini ve işletmelerin finansal sıkıntı düzeylerini hesaplarken kullanılan modellerdeki değişkenlere ulaşılamamıştır. Ayrıca, bazı şirketlerin bağımsız denetim raporlarına da ulaşılamamıştır. Geriye toplamda 1121 işletme'yıl gözlem kalmıştır. Veri seti dengesiz panel settir.

Bağımsız denetime ilişkin olan ve işletmelerin tahakkuk ve işlem esaslı kâr yönetimi büyüklükleri tespit edilirken kullanılan verilere Kamuyu Aydınlatma Platformunun (KAP) internet sitesi (www.kap.gov.tr) Borsa İstanbul'un internet sitesindeki (www.borsaistanbul.com) bağımsız denetim raporlarından ve finansal tablo/dipnotlarından ulaşılmıştır. Kurumsal sahipliğe ilişkin veriler; Türkiye Sermaye Piyasaları Birliği'nin (TSPAKB) internet sitesinde (www.tspakb.org.tr) yer alan veriler sayfasındaki yatırımcı profili bölümünden ve Merkezi Kayıt Kuruluşu'nun (MKK) internet sitesindeki (https://www.mkk.com.tr/wps/portal/MKK) e-veri bankasından ulaşılmıştır. Analizde kullanılan kontrol değişkenleri toplanırken KAP ve Borsa i̇stanbul'un internet sitesindeki işletmelerin finansal tabloları ve dipnotlarından yararlanılmıştır.

\subsection{Araştırma Modelleri}

Bağımsız denetim sonucu hazırlanan bağımsız denetim raporlarında karara varılan olumlu görüş dışındaki görüşlerde (şartlı görüş, görüş bildirmekten kaçınma, olumsuz görüş), işletmelerin gerçekleştirmiş oldukları tahakkuk ve işlem esaslı kâr yönetiminin etkisinin olup olmadığını tespit etmek amacı ile panel lojistik regresyon analizi gerçekleştirilmiştir ve havuzlandırımış veri yaklaşımı kullanılmıştır. Aşağıdaki ilk ampirik izah (Model 1), kâr yönetiminin olumlu görüş dışında görüş alma üzerinde etkisini test etmeye yöneliktir.

$$
\begin{aligned}
& \text { GORUS }_{i t}=\beta_{0}+\beta_{1} \text { TEKY }_{i t}\left(\text { ITEKY }_{i t}\right)+\beta_{2} \text { IEKY }_{i t}+\beta_{3} \text { DORTBUY }_{i t}+\beta_{4} \text { DENETILIS }_{i t}+\beta_{5} \text { KURSAH }_{i t}+\beta_{6} \\
& \text { ZMJSCore }_{i t}+\beta_{7} \text { AKTIFBUY }_{i t}+\beta_{8} \text { ZARAR }_{i t-1}+\beta_{9} \text { YAS }_{i t}+\varepsilon_{i t}
\end{aligned}
$$


Geçmiş dönemde finansal tablolara alınan olumlu görüş dışındaki görüşün mevcut dönemde denetim firması değişimine neden olup olmadığını tespit etmek amacı ile panel lojistik regresyon analizi gerçekleştirilmiştir ve havuzlandırılmış veri yaklaşımı kullanılmıştır. Aşağıdaki ikinci ampirik (Model 2 ) izah geçmiş dönemde alınan olumlu görüş dışındaki görüşün mevcut dönemde bağımsız denetim firması değişimine neden olup olmadığını test etmeye yöneliktir.

$D_{E G I S I M} i t=\beta_{0}+\beta_{1}$ GORUS $_{i t}+\beta_{2}$ DENETILIS $_{i t}+\beta_{3}$ ZARAR $_{i t-1}+\beta_{4} \triangle A K$ TIFBUY $_{i t}+\beta_{5} \Delta K U R S A H_{i t}+$

$\beta_{6} 20112012_{i t}+\beta_{7} 2013_{i t}+\varepsilon_{i t}$

Tablo 1. Değişkenler ve Ölçümü

\begin{tabular}{|c|c|c|}
\hline & Değişken & Ölçümü \\
\hline B. & GORUS $_{i t}$ & $\begin{array}{l}\text { i işletmesinin t zamandaki bağımsız denetim kuruluşunun vermiş olduğu görüş } \\
\text { olumsuz, şartlı veya görüş bildirmekten kaçınma şeklinde ise } 1 \text {; olumlu ise } 0\end{array}$ \\
\hline B. & $D E G I S I M_{i t}$ & i işletmesi t zamanda denetim firmasını değiştirmişse -1- değiştirmemişse -0- \\
\hline T. & TEKY $Y_{i t}$ & i işletmesinin t zamandaki Kothari Modeli'ne göre hesaplanan ihtiyari tahakkukları \\
\hline T. & $m_{-} T E K Y_{i t}$ & $\begin{array}{l}\text { i işletmesinin t zamandaki Kothari Modeli'ne göre hesaplanan ihtiyari } \\
\text { tahakkukların mutlak değerleri }\end{array}$ \\
\hline T. & $I E K Y_{i t}$ & $\begin{array}{l}\text { i işletmesinin t zamandaki Roychowdhury Modeli'ne göre hesaplanan anormal } \\
\text { faaliyet giderleri }\left(A F G_{i t}\right) \text { ve anormal üretim maliyetlerinin }\left(A \cup M_{i t}\right) \text { toplamı }\end{array}$ \\
\hline T. & GORUS $_{i t-1}$ & $\begin{array}{l}\text { i işletmesi bir önceki dönem finansal tablolarına olumlu görüş dışında (olumsuz, } \\
\text { şartlı, görüş bildirmekten kaçınma) bir görüş almışsa -1- olumlu görüş almışsa -0- }\end{array}$ \\
\hline K. & DORTBUY & $\begin{array}{l}\text { i işletmesinin t zamanda bağımsız denetimini gerçekleştiren bağımsız denetim } \\
\text { firması } 4 \text { büyük denetim firmasından (Deloitte, PriceWaterHouseCoopers, KPMG, } \\
\text { Ernst\&Young) biri ise } 1 \text {, değilse } 0 \text { ) }\end{array}$ \\
\hline K. & DENETILIS & $\begin{array}{l}\text { i işletmesinin bağımsız denetim firması ile olan mevcut yıl dahil geçmişe doğru } \\
\text { hesaplanan toplam iş ilişkisi süresi }\end{array}$ \\
\hline K. & DENETILIS $i t-1$ & $\begin{array}{l}\text { i işletmesinin denetim firmasını değiştirmeden önce t-1 zamanda çalıştığı denetim } \\
\text { firması ile geriye dönük toplam iş ilişki süresi }\end{array}$ \\
\hline K. & $K U R S A H_{i t}$ & $\begin{array}{l}\text { i işletmesinin t zamanda toplam sahiplik yapısı içinde yer alan kurumsal sahiplerin } \\
\text { oranı }\end{array}$ \\
\hline K. & $\triangle K U R S A H_{i t}$ & $\begin{array}{l}\text { i işletmesinin t-1 zamandan t zamana geçerken kurumsal sahiplik oranında } \\
\text { meydana gelen değişim }\end{array}$ \\
\hline K. & ZMJScore $_{i t}$ & $\begin{array}{l}\text { i işletmesinin t zamanda Zmijewski Modeli'ne (1984) göre finansal sıkıntı düzeyi } \\
\text { ZMJ= -4.336-4.512*(Net Kâr/Toplam Varlıklar)+5.679*(Toplam Yabancı } \\
\text { Kaynaklar/Toplam Varlıklar)+0.004*(Dönen Varlıklar/Kısa Vadeli Yabancı } \\
\text { Kaynaklar) }\end{array}$ \\
\hline K. & $A K T I F B U Y_{i t}$ & i işletmesinin t zamandaki aktif büyüklüğünün doğal logaritması \\
\hline K. & $\triangle A K T I F B U Y_{i t}$ & $\begin{array}{l}\text { i işletmesinin t-1 zamandan t zamana geçerken aktif büyüklüğünde meydana gelen } \\
\text { değişimin yüzdesi }\end{array}$ \\
\hline K. & $Z A R A R_{i t-1}$ & i işletmesinin t-1 zamanda zarar açıklamışsa 1, kâr açıklamışsa 0 \\
\hline K. & $Y A S_{i t}$ & i işletmesinin t zamandaki yaşının doğal logaritması \\
\hline K. & $20112012_{i}$ & örneklem içindeki işletme 2011,2012 yıllarında ise 1 değil ise 0 değeri \\
\hline K. & $2013_{i}$ & örneklem içindeki işletme 2013 yıllarında ise 1 değil ise 0 değeri \\
\hline
\end{tabular}

\subsubsection{Bağımlı Değişkenler}

Birinci modelde (1) bağımlı değişken olan denetim görüşü (GORUS ${ }_{i t}$ ) dört farklı şekilde olabilmektedir. Bu görüşler olumlu, olumsuz, şartlı ve görüş bildirmekten kaçınma şeklindedir. Birinci modelde bağımlı değişkenimiz kukla değişkenle ölçülmüştür. Çalışmada eğer i işletmesinin $t$ zamanda bağımsız denetim firmasından almış olduğu denetim görüşü olumsuz, şartlı veya görüş bildirmekten 
kaçınma şeklinde ise 1; olumlu ise 0 ile ölçülmüştür. İkinci modelde (2) bağımlı değişken olan denetim firmasının değişimi $\left(D E G I S I M_{i t}\right)$ kukla değişkenle ölçülmüştür. Eğer i işletmesi t zamanda bağımsız denetim firmasını değiştirmişse 1; değiştirmemişse 0 ile ölçülmüştür.

\subsubsection{Test Edilecek Değişkenler}

Aşağıda model 1 ve model 2'de test edilecek değişkenler detaylı bir biçimde açıklanmıştır.

\section{Kâr Yönetimi ve Bağımsız Denetim Görüşü Arasındaki ilişsiyi Test Etmeye Yönelik Değişkenler (1. Model)}

Tahakkuk Esası Kâr Yönetimi (ihtiyari Tahakkuklar): Çalışmada ilk hipotezi test etmek amacı ile kullanılan tahakkuk esaslı kâr yönetiminin göstergesi olan ihtiyari tahakkukları tespit ederken Kothari, Leone ve Wasley (2005)'in performans eşlemeli modeli (Model 3) kullanılmıştır. Bu model, Jones Modeli ve Değiştirilmiş Jones Modelinin geliştirilmiş halidir. Jones Modeli ihtiyari tahakkukları belirleme aşamasında alacaklardaki değişimi dikkate almadığından hatalı sonuçlar verebilmektedir. Çünkü, alacaklar kârı yönetmek için uygun bir kalemdir. Dechow, Sloan ve Sweeney (1995), Jones Modeli'nin bu eksiğini fark ederek Jones Modeli'ne alacaklardaki değişimi de ekleyerek oluşabilecek hatalı sonuçların önüne geçmeye çalışmışlardır. Değiştirilmiş Jones Modeli ise intiyari tahakkukları belirleme aşamasında bir önceki yılın aktif kârlılı̆ını dikkate almamaktadır. Kothari, Leone ve Wasley (2005), Değiştirilmiş Jones Modeli'ne göre tespit edilen ihtiyari tahakkukların, işletmelerin aslında aşırı farklı performans sergilemelerinden kaynaklandığını gözlemlemişlerdir. Bu yüzden Değiştirilmiş Jones Modeli'ndeki performans farklılığından kaynaklanabilecek olası hatanın önüne geçmek amacı ile aktif kârlılık değişkenini eklemişlerdir. Bu çalışmada bu hatalı sonuçların önüne geçebilmek amacı ile Kothari, Leone ve Wasley (2005)'in performans eşlemeli modeli kullanıımıştır. Modelin (3) ampirik izahı aşağıda olduğu gibidir.

$T T_{i t} / A_{i t-1}=\alpha i\left(1 / A_{i t-1}\right)+\beta_{1 i}\left(\Delta S A T D E G_{i t} / A_{i t-1}\right)+\beta_{2 i}\left(M D V_{i t} / A_{i t-1}\right)+\beta_{3} R O A_{i t-1}+\varepsilon_{i t}$

Model 3'te, ilk olarak bir yılda bir sektörde yer alan her bir işletmenin toplam tahakkukları $\left(T T_{i t}\right)$ bilanço yaklaşımına ${ }^{1}$ göre hesaplanmaktadır. Daha sonra bir yılda bir sektördeki bütün işletmeler için hesaplanan toplam tahakkuklar ile yine aynı yılda aynı sektördeki işletmelerin bir önceki döneme göre satış gelirlerinde meydana gelen değişim $\left(\triangle S A T D E G_{i t}\right)$ ve brüt maddi duran varlık toplamı $\left(M D V_{i t}\right)$ ve bir önceki yıl aktif kârlıık oranı $\left(R O A_{i t-1}\right)$ ile en küçük kareler yöntemi kullanılarak regresyona tabi tutulmaktadır. Değişen varyans probleminin önüne geçmek amacı ile modelde kullanılan her bir değişken işletmelerin bir önceki yılın aktif toplamına $\left(A_{i t-1}\right)$ oranlanmaktadır. Elde edilen alfa ve beta katsayıları daha sonra aşağıdaki modelde (Model 4) o yıl ve o sektöre göre toplam tahakkukların beklenen seviyesini hesaplamak için kullanılmaktadır.

$T \hat{T}_{i t} / A_{i t-1}=\hat{\alpha}_{i}\left(1 / A_{i t-1}\right)+\beta_{1 i}\left(\Delta S A T D E G_{i t}-\Delta A L D E G_{i t} / A_{i t-1}\right)+\beta_{2 i}\left(M D V_{i t} / A_{i t-1}\right)+\beta_{3 i}^{r} R O A_{i t-1}+\varepsilon_{i t}$

En son aşamada (aşağıdaki eşitlik), toplam tahakkukların beklenen değeri ile gerçekleşen değeri arasındaki fark tahakkuk esaslı kâr yönetiminin göstergesi olan ihtiyari tahakkuk tutarı $\left(I T_{i t}\right)$ olarak ele alınmaktadır.

$T \hat{T}_{i t} / A_{i t-1}-T T_{i t} / A_{i t-1}=I T$ it

Ihtiyari tahakkuk tutarları negatif veya pozitif olabilmektedir. İlk iki hipotezi $\left(\mathrm{H}_{1 \mathrm{~A}}\right.$ \& $\left.\mathrm{H}_{1 \mathrm{~B}}\right)$ test ederken, ihtiyari tahakkukların hem işaretli değerleri hem mutlak değerleri kullanılmıştır. Kâr yönetimi ve bağımsız denetim görüşü arasındaki ilişkiye yönelik olan 1 . Model bu yüzden ihtiyari tahakkukların hem işaretli yönleri hem de mutlak değerleri ile ayrı ayrı çalıştırılmıştır.

İşlem Esaslı Kâr Yönetimi (Anormal Faaliyet Giderleri ve Anormal Üretim Maliyetleri): İşlem esaslı kâr yönetiminin tespitine yönelik araştırmalar, tahakkuk esaslı kâr yönetiminin tespitine yönelik araştırmalar kadar eski olmamakla birlikte, konu ile ilgili ilk göze çarpan model Jackson ve Wilcox (2000) Modeli'dir. Model muhasebe döneminin son çeyreğindeki satışlara odaklanmakta ve işletmelerin kârlılık hedeflerine 
ulaşmak amacı ile bir muhasebe döneminin son çeyreğinde satış indirimleri yaptığından yola çıkılarak kurgulanmıştır. İşlem esaslı kâr yönetiminin tespitine yönelik geliştirilmiş diğer bir model ise Herrmann, Inoue ve Thomas (2003) Modeli'dir. Model Jackson ve Wilcox (2000) Modeli'nde olduğu gibi işletmelerin kârlılık hedeflerini yakalamaya yönelik olmasından yola çıkmaktadır. İşletmelerin yöneticileri kârlılık beklentilerini karşılayamadıkları zaman kârlı varlık satışı yaparak işlem esaslı olarak kârı yönettikleri üzerine kurgulanmıştır. İşlem esaslı kâr yönetimini tespit etmeye yönelik bir diğer model ise Roychowdhury Modeli (2006, s.335-370)'dir. Bu çalışmada işlem esaslı kâr yönetimi tespit edilirken Roychowdhury Modeli (2006, s.335-370) kullanıımıştır. Model yukarıda bahsi geçen işlem esaslı kâr yönetimini tespit etmeye yönelik modellerde olduğu gibi tek bir 'işleme' odaklanmamaktadır. Bu yüzden birçok araştırmacının kullandığı modeldir (Cohen ve Zarowin, 2010; Cohen, Dey ve Lys, 2008; Visvanathan,2008; Kang ve Kim, 2012; Chi, Lizic ve Pevzner, 2011). Bu çalışmada da bu nedenle Roychowdhury Modeli (2006) kullanılmıştır.

Roychowdhury' e (2006) göre muhasebeye konu olan işlemler 3 şekilde tasarlanarak kâr işlem esaslı olarak yönetilebilir. Bunlar, (i) muhasebeye konu olmadan önce satışların zamanlaması ayarlanarak; (ii) esas faaliyet konusu gerçekleştirilirken katlanılan faaliyet giderleri olan pazarlama-satış-dağıtım, araştırmageliştirme ve genel yönetim giderlerinin zamanlaması ayarlanarak veya (iii) talep edilenin üzerinde üretim gerçekleştirilerek/stoklama yapılarak kâr yönetilebilmektedir. Bu yüzden Roychowdhury (2006) üç gösterge ile işletmelerin işlemleri tasarlayarak kârı ne kadar yönettiklerini tespit etmiştir. Bunlardan ilki anormal nakit akışı, ikincisi anormal faaliyet giderleri ve son olarak anormal üretim maliyetleridir. Çalışmada Cohen vd. (2008), Ge ve Kim (2014)'in ele aldığı gibi Roychowdhury Modeli'nin (2006) iki aşaması olan anormal faaliyet giderleri ve anormal üretim maliyetinin toplamı işlem esaslı kâr yönetiminin göstergesi olarak ele alınmıştır.

Roychowdhury Modeli'ne (2006) göre, anormal faaliyet giderleri hesaplanırken, bir yılda bir sektörde yer alan işletmelerin satışları $\left(S A T_{i t}\right)$ faaliyet giderleri $\left(F A A L G I D_{i t}\right)$ ile en küçük kareler yöntemi kullanarak regresyona tabi tutulmaktadır. Modelin çalıştııılması sonucu elde edilen hata terimi $\left(\varepsilon_{i t}\right)$ işlem esaslı kâr yönetiminin göstergesi olan anormal faaliyet giderleri $\left(A F G_{i t}\right)$ olarak ele alınmaktadır. Yine modelde değişen varyans sorunun önüne geçmek amacı ile her bir değişken işletmelerin bir önceki yılın aktif toplamına $\left(A_{i t-1}\right)$ oranlanmaktadır (6. Model)

FAALGID $D_{i t} / A_{i t-1}=\alpha_{i 0} 1 / A_{i t-1}+\alpha_{i 1} S A T_{i t} / A_{i t-1}+\varepsilon_{i t}$

Roychowdhury Modeli'ne (2006) göre, üretim maliyetinin anormal kısmı hesaplanırken, ilk olarak üretim maliyeti (URMAL ${ }_{i t}$ ), satılan $\mathrm{mal} /$ mamüllerin maliyeti $\left(S A T M A L_{i t}\right)$ ve stoklarda bir önceki yıla göre meydana gelen değişimin $\left(\triangle S T O K D E G_{i t}\right)$ toplamı olarak ele alınmıştır (7. Model)

$U_{R M A L_{i t}}=S_{A T M A L_{i t}}+\triangle S T O K D E G_{i t}$

Daha sonra üretim maliyeti formülündeki her bir değişken için tahmin modeli oluşturulmuştur. Tahmin modellerinde değişen varyans sorunun önüne geçmek amacı ile her bir değişken işletmelerin bir önceki yılın aktif toplamına $\left(A_{i t-1}\right)$ oranlanmaktadır (8. Model)

SATMAL ${ }_{i t} / A_{i t-1}=\alpha_{i 0}+\alpha_{i 1}\left(1 / A_{i t-1}\right)+\beta_{i 1}\left(S A T_{i t} / A_{i t-1}\right)+\varepsilon_{i t}$

Illk olarak, bir yılda bir sektörde yer alan işletmelerin sattıkları mal/mamüllerin maliyeti $\left(S A T M A L_{i t}\right)$ satışlar $\left(S A T_{i t}\right)$ ile en küçük kareler yönetimi kullanarak regresyona tabi tutulmakta ve elde edilen hata terimi $\left(\varepsilon_{i t}\right)$ satılan mal/mamül maliyetine eklenerek, satılan mal/mamül maliyetinin o yılki satşlara göre olması gereken miktarı (SATMAL ${ }_{i t}$ ) hesaplanmaktadır (8. Model)

$\triangle S T O K D E G_{i t} / A_{i t-1}=\alpha_{i 0}+\alpha_{i 1}\left(1 / A_{i t-1}\right)+\beta_{i 1}\left(\Delta S A T D E G_{i t} / A_{i t-1}\right)+\beta_{i 2}\left(\Delta S A T D E G_{i t-1} / A_{i t-1}\right)+\varepsilon_{i t}$

Benzer tahmin modeli, üretim maliyeti denklemindeki (7.Eşitlik) stoklardaki bir önceki yıla göre meydana gelen değişim $\left(\triangle S T O K D E G_{i t}\right)$ için de kullanılmıştır. Bir yılda bir sektörde yer alan işletmelerin 
stoklarında bir önceki yıla göre meydana gelen değişim $\left(\triangle S T O K D E G_{i t}\right)$, bir önceki dönem $\left(\triangle S A T D E G_{i t}\right)$ ve ondan önceki dönemde satışlarda meydana gelen değişimle $\left(\triangle S A T D E G_{i t-1}\right)$ en küçük kareler yöntemi kullanarak regresyona tabi tutulmakta ve elde edilen hata terimi $\left(\varepsilon_{i t}\right)$ stoklarda bir önceki yıla göre meydana gelen değişime eklenerek, stoklarda bir önceki yıla göre olması gereken değişim miktarı ( $\left.\triangle S T O \widehat{K} D E G_{i t}\right)$ hesaplanmaktadır (9. Model)

$U R M A L_{i t} / A_{i t-1}=\alpha_{i 0}+\alpha_{i 1}\left(1 / A_{i t-1}\right)+\beta_{i 1}\left(S A T_{i t} / A_{i t-1}\right)+\beta_{i 2}\left(\Delta S A T D E G_{i t} / A_{i t-1}\right)+\beta_{i 3}\left(\Delta S A T D E G_{i t-1} / A_{i t-1}\right)+\varepsilon_{i t}$

Roychowdhury Modeline (2006) göre, üretim maliyeti denklemindeki üretim maliyeti $\left(U R M A L_{i t}\right)$ için de bir tahmin modeli oluşturulmuştur. Bir yılda bir sektördeki işletmelerin üretim maliyetleri (URMAL ${ }_{i t}$ ) satışlar $\left(S A T_{i t}\right)$, satışlardaki bir önceki $\left(\triangle S A T D E G_{i t}\right)$ ve ondan önceki yıla göre meydana gelen değişimle $\left(\triangle S A T D E G_{i t-1}\right)$ en küçük kareler yöntemi kullanarak regresyona tabi tutulmakta ve elde edilen hata terimi $\left(\varepsilon_{i t}\right)$ üretim maliyetine eklenerek, o yılki her bir işletme için olması gereken üretim miktarı tutarı (URM̂ALit) hesaplanmaktadır (10. Model)

$A U M_{i t}=U R \hat{M} A L_{i t} / A_{i t-1}-\left(S A T \hat{M} A L_{i t} / A_{i t}-1+\triangle S T O R D E G_{i t} / A_{i t-1}\right)$

En nihai olarak elde edilen olması gereken satlan mal/mamül maliyeti (SATMA $\mathrm{L}_{i t}$ ) ve olması gereken stoklardaki değişim miktarı toplanmakta ( $\triangle S T O \hat{R} D E G_{i t}$ ), tahmin modeli sonucu hesaplanan olması gereken üretim miktarı tutarından çıkarılarak (URM̂A $L_{i t}$ ), işlem esaslı kâr yönetiminin göstergesi olan anormal üretim maliyeti $\left(A \cup M_{i t}\right)$ hesaplanmaktadır (11. Model)

IEKY $Y_{i t}=A \cup M_{i t}+A F G_{i t}$

İşlem esaslı kâr yönetiminin (IEKY ${ }_{i t}$ ) gösteresi olarak Cohen vd. (2008), Ge ve Kim (2014)'in ele aldığı gibi anormal üretim maliyetleri $\left(A \cup M_{i t}\right)$ ve anormal faaliyet giderlerinin $\left(A F G_{i t}\right)$ toplamı olarak ele alınmıştır (12. Model)

\section{Geçmiş Yıl Bağımsız Denetim Görüşü ve Denetim Firması Değişikliği Arasındaki ilişkiyi Test Etmeye Yönelik Değişken (2. Model)}

Geçmiş Dönem Bağımsız Denetim Görüşü: Model 2'deki test değişkeni, GORUS işletme bir önceki dönem finansal tablolarına olumlu görüş dışında bir görüş almışsa 1 , olumlu görüş almışsa 0 ile ifade edilmiştir.

\subsubsection{Kontrol Değişkenleri}

Aşağıda 1. model ve 2. Modelde kullanılan kontrol değişkenleri detaylı bir bir biçimde açıklanmıştır.

Kâr Yönetimi ve Bağımsız Denetim Görüşü Arasındaki ilişkiye Yönelik Modeldeki Kontrol Değişkenleri (1.Model)

Denetim görüşünü etkileyebilecek kontrol değişkenleri geçmişte konuya ilişkin çalışmalardan yola çıkılarak oluşturulmuştur. Bunlardan ilki işletmenin bağımsız denetiminin 4 büyük denetim firmasından (PriceWaterHouseCoopers, Deloitte, KPMG, Ernst\&Young) biri tarafından yapılıp yapılmadığıdır. Büyük denetim kuruluşları küçük denetim kuruluşlarına göre daha fazla müşteriye sahip olduklarından denetledikleri işletmelerden gelebilecek -olumlu- görüş verme baskısına karşı daha fazla dirençli olmakta ve daha kaliteli bağımsız denetim hizmeti sunmaktadır. Diğer bir ifade ile büyük denetim kuruluşlarının işletmelerin finansal tablolarına olumlu görüş dışındaki görüşlerden birini verme ihtimali küçük denetim kuruluşlarına göre daha yüksektir (Chen, Chen ve Su, 2001; Boone, Khurana ve Raman, 2010; Chan, Lin ve Mo, 2006 ; DeAngelo, 1981; DeFond,Wong ve Li, 2000; Francis ve Yu, 2009; Geiger ve Rama, 2006).

Bir diğer kontrol değişkeni, denetlenen işletmenin bağımsız denetim firması ile olan iş ilişkisi süresi (DENETILIS $\left.{ }_{i t}\right)^{\prime}$ dir. Literatürde yaygın olan kanı denetlenen işletmenin bağımsız denetim kuruluşu ile olan iş ilişki süresi arttıkça bağımsız denetim kuruluşu ile denetlenen işletme arasında bir yakınlık doğacağından 
bağımsız denetim kuruluşunun bağımsızlığının tehlikeye düşeceğidir (Davis, So ve Trompeter, 2000; Chin, Lisic ve Pevzner, 2011). Bağımsız denetim kuruluşu işletmenin finansal tablolarına olumlu görüş dışında bir görüş vermesi gerektiği durumlarda, doğan yakınlıktan dolayı olumlu görüş verme eğiliminde olmaktadır (Vanstraelen, 2000).

Çalışmada kullanılan bir diğer kontrol değişkeni kurumsal sahiplik oranıdır $\left(K U R S A H_{i t}\right)$. Kurumsal yatırımcılar, inançlı mülkiyet ve profesyonel yönetim anlayışına göre hareket ederek çeşitli şirketlerin hisselerine yatırım yapmaktadır. Bu yatırımcılar kendilerine emanet edilen fonlar ile çeşitli farklı işletmelerin hisse senetlerine yatırım yapmakta ve inançlı mülkiyet esasına göre bu emanet edilen fonları sanki kendi fonlarıymış gibi çıkarlarının üzerinde tutmaktadırlar. Chung ve Zhang'a (2011) göre bu emanet fonlar, kurumsal yatırımcılar tarafından kendi fonlarıymış gibi sahiplenildiğinden, işletmede gerçekleşebilecek kâr yönetimi uygulamaları etkin bir şekilde kontrol edip gözetlenecektir. Kurumsal yatırımcılar profesyonel yönetim anlayışı ile yönettiğinden menkul kıymet piyasasındaki gelişmeleri yakından takip etmek için yeterli bilgi birikimine ve bireysel yatırımcıların aksine, yatırım yaptıkları işletmelerin muhasebe verileri hakkında daha detaylı bilgiye sahiptir (Sermaye Piyasası Kurulu, Yatırımcı Bilgilendirme Kitapçıkları 3, Yatırım Fonları, 2010:s.15-16; Jiambalvo, Rajgopal, Venkatachalam, 2002). Kurumsal yatırımcıların işletme hakkında piyasayı yakından takip etmesi, daha detaylı bilgiye sahip olması ve emanet fonları kendi çıkarlarının üstünde tutması işletmede gerçekleşen kâr yönetimi uygulamalarını etkin bir şekilde kontrol edip gözetlemesine neden olması beklenmektedir. Etkin kontrol ve gözetim kâr yönetimi uygulamalarını engellemekle birlikte, finansal tablolara olumlu görüş dışında bir görüş alma olasııı̆ını azalması beklenmektedir.

Büyük işletmelerin küçük işletmelere göre finansal yapıları daha sağlıklıdır ve finansal açıdan daha istikrarlıdır. Finansal açıdan sağııkı ve istikrarlı olan işletmelerin finansal tablolarında manipülatif işlemlere rastlama olasılığı daha düşük olması beklenmektedir. Bu yüzden işletmenin büyüklüğü (AKTIFBUY $\left.{ }_{i t}\right)$ ile olumlu görüş dışında bir görüş alma durumu arasında negatif ilişki mevcuttur (Chan vd., 2006; Chan, Lin ve Wong; 2010; Chen vd., 2001; Monroe ve Teh, 1993). Geçmiş yılda zarar etmiş olan işletmeler, mevcut dönemde tekrar zarar açıklamak yerine kâr açıklamak amacı ile finansal tablolarda manipülatif işlemlere başvurabilmektedirler. Bu yüzden geçmiş yılda zarar açıklama durumu (ZARAR $\left.R_{i t-1}\right)$ ile mevcut dönemde olumlu dışında bir görüş alma durumu arasında pozitif bir ilişki mevcuttur (Chan, Lin ve Mo, 2006).

Kullanılan diğer kontrol değişkeni ise işletmenin yaşıdır $\left(Y A S_{i t}\right)$. İşletmenin yaşı ne kadar genç ise finansal sıkıntı ile karşılaşma olasııı̆ı o kadar yüksek olması beklenmektedir. Bu durumda yeni kurulmuş ve genç olan işletmelerin finansal tablolarına olumlu dışında görüş verilme olasııı̆̆ daha yüksektir (Dopuch, Holthausen ve Leftwich, 1986; Monroe ve Teh.,1993; Carey ve Simnett; 2006). Kullanılan son ve önemli kontrol değişkeni işletmelerin Zmijewski Modeli'ne (1984) göre tespit ettiğimiz finansal sıkıntı seviyeleridir $\left(Z M J S c o r e_{i t}\right)$. Bu değişkenin değerinin büyüklüğü (küçüklüğü) işletmelerin finansal sıkıntıda olduğunu (finansal sıkıntıdan uzak olduğunu) göstermektedir. Iş̧letmelerin finansal sıkıntı düzeyleri arttıkça süreklilikleri tehlikeye düşmekte ve bu yüzden finansal tablolarına olumlu görüş dışında bir görüş alabilmektedirler. Bu değişkenin kontrol değişkeni olarak modelde yer alması ile finansal tablolarına olumlu görüş dışında görüş almada tahakkuk ve işlem esaslı kâr yönetimi uygulamalarının etkisi açık bir şekilde görülmesi beklenmektedir. Böylece Butler vd. (2004), Herbohn vd. (2008) bulgularının ve savunduklarının Türkiye perspektifinden geçerliliği kontrol edilecektir.

\section{Geçmiş Yıl Bağımsız Denetim Görüşü ve Denetim Firması Değişikliği Arasındaki ílişkiye Yönelik Kontrol Değişkenleri (2. Model)}

Denetim firması değişim kararını etkileyebilecek kontrol değişkenleri geçmişte konuya ilişkin yapılmış olan çalışmalardan yola çıkarak ve Türkiye'ye özgü bir kontrol değişkeni eklenerek oluşturulmuştur. Chan, Li ve Mo (2006) ve Nasser, Wahid, Nazri ve Hudaib (2006)'a göre işletmenin aktif büyüklüg̈ünde meydana gelen değişim denetim firması değişikliğine neden olabilmektedir. İşletme büyüdükçe (Küçüldükçe) büyük denetim firmaları (Küçük denetim firmaları) ile çalışma isteğinde olmaktadır. Bu yüzden denetim firmasını değiştirme eğiliminde olabilmektedir. Çalışmada da, işletmenin büyümesinin veya küçülmesinin göstergesi olarak aktif büyüklükte bir önceki döneme göre meydana gelen değişimin yüzdesi $\left(\triangle A K T I F B U Y_{i t}\right)$ kontrol değişkeni olarak kullanılmıştır. 
Geçmiş dönemde zarar açıklayan işletmeler mevcut dönemde bu durumun üstesinden gelebilmek için kârı arttırıcı manipülatif işlemlerde bulunabilmekte ve manipülatif işlemleri gizlemek adına mevcut dönemde denetim firmasını değiştirme eğiliminde olabilmektedir (Chan, Li ve Mo, 2006). Bu bağlamda kullanılan diğer kontrol değişkeni $\left(Z A R A R_{i t-1}\right)$ 'dır.

Han, Kang ve Rees (2009)'a göre kurumsal sahipler, kurumsal yönetişimin temeli olan etkin kontrol ve gözetimi sağlamak adına büyük denetim şirketleri ile çalışmaktadır. Yapmış oldukları çalışmada da uzun dönemli kurumsal sahiplik oranı ile 4 büyük denetim şirketi seçimi arasında pozitif anlamlı ilişki tespit etmişlerdir. Bu görüşten yola çıkarak işletmelerde kurumsal sahiplik oranı arttıkça 4 büyük denetim firması ile çalışma eğiliminin artması beklenmektedir. Bu yüzden küçük denetim firmaları ile çalışan işletmeler kurumsal sahiplik oranının artmasına bağlı olarak denetim firması değiştirme eğiliminde olacağından çalışmada kontrol değişkeni olarak kurumsal sahiplik oranında bir önceki döneme göre meydana gelen değişim $\left(\triangle K U R S A H_{i t}\right)$ kullanılmıştır.

Nasser, Wahid, Nazri ve Hudaib (2006), Malezya'da 1990-2000 yılları arasında 297 işletme üzerine yapmış olduğu çalışmada, denetim firması değişmeden önce çalışılan denetim firmasının 4 büyük denetim firmasından biri olması ve bu firmalarla iş ilişki süresinin fazla olması ile denetim firması değişikliğine gidilmesi arasında pozitif anlamlı ilişkiye rastlamışlardır. Çalışılan denetim firması ile olan iş ilişki süresi arttıkça denetim firması ve işletme arasında doğacak yakınlıktan dolayı denetim firmasının bağımsızlığı tehlikeye düşmekle birlikte, işletmeler bağımsız denetim fonksiyonun etkin bir şekilde yerine getirildiğine dair işletmenin taraflarının güvenini sarsmamak adına denetim firmasını değiştirme eğiliminde olmaktadır (Nasser \& Wahid \& Nazri \& Hudaib, 2006). Bu yüzden çalışmada kontrol değişkeni olarak kullanılan diğer değişken işletmenin denetim firması değişmeden önce çalıştığı denetim firması ile olan iş ilişki süresi (DENETILIS it-1 $_{1}$ 'dir.

Türkiye'de, 2009 yayınlanan "Sermaye Piyasasında Bağımsız Denetim Standartları Hakkında Tebliğde Değişiklik Yapılmasına Dair Tebliğ'e göre bazı istisnai durumlar hariç aynı denetim firması ile en fazla 7 yıl çalışılmasına ilişkin, 2011 yılından itibaren geçerli olmak üzere bir düzenleme yapılmıştır. İşletmeler, en az 25 adet sorumlu ortak baş denetçi ve toplamda en az 75 kişiden oluşan denetim kadrosuna sahip bağımsız denetim firmaları ile çalışılması durumunda 7 yıllık azami süre uygulamasından istisna tutulmuşlardır. Bu bağlamda, 2011, 2012 yıllarında aynı denetim firması ile azami 7 yıllık çalışma süresini doldurmuş işletmeler denetim firması değişikliği gerçekleştireceklerdir veya en az 25 sorumlu ortak baş denetçi ve toplamda 75 kişiden oluşan denetim kadrosuna sahip firmalar ile çalışılması durumunda 7 yıllık süreden muafiyetten dolayı denetim firması değişimi gerçekleşmeyecektir (SPK, Seri X, No:25: Sermaye Piyasasında Bağımsız Denetim Standartları Hakkında Tebliğde Değişiklik Yapılmasına Dair Tebliğ). Bu bağlamda, çalışmada kontrol değişkeni olarak yıl değişkeni $\left(20112012_{i}\right.$ ) kullanılmıştır. Eğer örneklem içindeki işletme 2011, 2012 yıllarında ise 1, değil ise 0 değerini almıştır.

2013 yılında ise geçmişte yapılmış olan bütün düzenlemelerin geçerliliğini ortadan kaldıran bir karara varılmıştır (6102 Sayılı TTK, Madde 400). Bu karara göre, denetim firmalarının rotasyonunda geçmiş 10 yıllık döneme bakılacak ve geçmiş 10 yıl içinde toplamda 7 yıl aynı denetim firması ile çalışılması durumunda denetim firması değişikliğine gidilecektir. Ve bu denetim firması ile 3 yıl boyunca tekrar çalışılamayacaktır. Bu bağlamda, çalışmada kontrol değişkeni olarak başka bir yıl değişkeni kullanılmıştır. Eğer örneklem içindeki işletme 2013 yılında ise 1 değil ise 0 değerini almıştır (2013i).

\section{Araştırmanın Sonuçları}

Aşağıda araştırmaya ilişkin tanımlayıcı istatistiklere ve regresyon sonuçlarına yer verilmiştir.

\subsection{Tanımlayıcı İstatistikler}

Aşă̆ıda modellerde kullanılan sıralı ve sürekli değişkenlere ilişkin tanımlayııı istatistiklere yer verilmiş̧ir. 
Kâr Yönetimi, Bağımsız Denetim Görüşü ve Denetim Firması Değişimi Arasındaki illişkiler: Borsa İstanbul İmalat Sektörüne Yönelik Bir Araştırma

Tablo 2. Süreli Değişkenlere İlişkin Tanımlayıcı İstatistikler

\begin{tabular}{|l|c|c|c|c|c|c|}
\hline & TEKY $_{i t}$ & $m_{-}$TEKY $_{i t}$ & IEKY $_{i t}$ & ZMJSCore $_{i t}$ & DENETILIS $_{\text {it }}$ & DENETILIS $_{\text {it-1 }}$ \\
\hline Ort, & 0,015374 & 0,18847 & $-0,006225$ & $-1,586532$ & 4,353256 & 4,524532 \\
\hline Ortan, & 0,029653 & 0,12275 & 0,000311 & $-1,969323$ & 4,000000 & 4,000000 \\
\hline Std, Sap, & 0,281663 & 0,20980 & 0,137876 & 3,141640 & 3,100131 & 3,12158 \\
\hline Gözlem & 1121 & 1121 & 1121 & 1121 & 1121 & 1121 \\
\hline & KURSAH $_{i t}$ & $\Delta K U R S A H_{i t}$ & AKTIFBUY & & $\Delta$ it & \\
\hline Ort, & 0,363902 & 0,013933 & 19,27139 & 0,065779 & 39,04906 & \\
\hline Ortan, & 0,300728 & 0,000187 & 19,19644 & 0,072782 & 39,00000 & \\
\hline Std, Sap, & 0,302745 & 0,167053 & 1,486717 & 0,192303 & 12,53040 & \\
\hline Gözlem & 1121 & 1121 & 1121 & 1121 & 1121 & \\
\hline
\end{tabular}

Tablo 2'ye göre toplam gözlemdeki işletmelerin denetim firmaları ile olan ilişki süresi (DENETILIS it $_{\text {) }}$ ortalama 4,35 yıldır. Denetim firması değiştirmeden önce çalıştıkları denetim firmaları (DENETILIS ${ }_{i t-1}$ ) ile ortalama 4,52 yıl çalışmışlardır. Kurumsal sahiplik oranı ( $\left.K U R S A H_{i t}\right)$ toplam gözlemde \%36,39'dur. Kurumsal sahiplik oranı ( $\triangle K U R S A H_{i t}$ ) bir önceki yıla göre toplam gözlemde ortalama \%1,39 artmıştır. Aktif büyüklük $\left(\triangle A K T I F B \cup Y_{i t}\right)$ toplam gözlemde bir önceki yıla göre ortalama \%6,57 artmıştır. Toplam gözlemdeki işletmelerin yaşı $\left(Y A S_{i t}\right)$ ortalama 39,04'tür. İhtiyari tahakkukların (işaretli) (TEKY $Y_{i t}$ ) ortalaması 0,015374 olup, işletmelerin genellikle kârı arttırıcı ihtiyari tahakkuka başvurdukları söylenebilir. Ihtiyari tahakkukların mutlak değerlerinin $\left(m_{-} T E K Y_{i t}\right)$ ortalaması ise 0,18847 'dir. İşlem esaslı kâr yönetiminin (IEKY $\left.Y_{i t}\right)$ göstergesi olan anormal üretim maliyeti ve anormal faaliyet giderlerinin toplamının ortalaması $-0,006225^{\prime}$ tir. ZMJscore'un ortalaması -1,586532 olup işletmelerin genellikle finansal sıkıntı düzeylerinin yüksek olmadığını söyleyebiliriz.

Tablo 3. Kukla Değişkenlere ilişkin Tanımlayıcı İstatistik

\begin{tabular}{|l|l|l|l|l|l|l|l|}
\hline Değişken & & Oran & Sayı & Değişken & & Oran & Sayı \\
\hline \multirow{2}{*}{ GORUS $_{i t}$} & 0 & $\% 89,20$ & 1001 & \multirow{2}{*}{ DORTBUY $_{i t}$} & 0 & $\% 44,42$ & 498 \\
\cline { 2 - 3 } & 1 & $\% 10,70$ & 120 & & 1 & $\% 55,58$ & 623 \\
\hline \multirow{2}{*}{ GORUS $_{i t-1}$} & 0 & $\% 91,001$ & 1020 & \multirow{2}{*}{ ZARAR $_{i t-1}$} & 0 & $\% 68,77$ & 771 \\
\cline { 2 - 3 } & 1 & $\% 9,009$ & 101 & & $\% 31,22$ & 350 \\
\hline \multirow{2}{*}{ DEGISIM $_{i t}$} & 0 & $\% 78,67$ & 882 & & & & \\
\cline { 2 - 3 } & 1 & $\% 21,33$ & 239 & & & & \\
\hline
\end{tabular}

Tablo 3'te 120 adet işletmenin finansal tablolarına olumlu görüş dışında görüş (GORUS ${ }_{i t}$ ) (şartlı, olumsuz, görüş bildirmekten kaçınma) aldıklarını görmekteyiz. Örneklemdeki 623 işletmenin bağımsız denetimi 4 büyük denetim firmasından (DORTBUY ${ }_{i t}$ ) biri tarafından gerçekleştirilmektedir. Bir önceki dönem 101 işletme finansal tablolarına olumlu görüş dışında görüş almış olup, 239 işletme mevcut dönemde denetim firmasını (DEGISIM ${ }_{i t}$ ) değiştirmiştir. 239 adet değişimden 81'i 4 büyük denetim firmasından 4 büyük denetim firmasına, 21'i 4 büyük denetim firmasından 4 büyük denetim firması dışındaki firmaya, 93'ü 4 büyük denetim firması dışındaki firmadan yine 4 büyük denetim firması dışındaki firmaya, 43 'ü 4 büyük denetim firması dışındaki denetim firmasından 4 büyük denetim firması yönündedir. Denetim firması değiştiren 239 işletmenin 38'i geçmiş dönemde, 39'u mevcut dönemde finansal tablolarına olumlu görüş dışında görüşlerden birini almıştır. 350 işletme ise geçmiş dönemde zarar $\left(Z A R A R_{i t-1}\right)$ açıklamıştır.

\subsection{Regresyon Sonuçları}

Aşağıda ilk olarak tahakkuk ve işlem esaslı kâr yönetiminin olumlu görüş dışındaki görüşler üzerindeki etkisi, daha sonra geçmiş dönemde finansal tablolara alınan olumlu görüş dışındaki görüşlerin denetim firması değişimi üzerindeki etkisine yönelik sonuçlara yer verilmiştir. 
4.2.1 Tahakkuk ve İşlem Esaslı Olarak Kârın Yönetilmesi İşletmelerin Olumlu Görüş Dışında Bir Görüş Alma Olasılığını Arttırmakta Mıdır?

Aşağıda ilk olarak tahakkuk ve işlem esaslı kâr yönetiminin işletmelerin finansal tablolarına olumlu görüş dışında bir görüş alma durumu arasındaki ilişkiye yönelik havuzlanmış lojistik regresyon sonuçları verilmiştir.

Tablo 4. 1.Model 1 İçin Havuzlanmış Lojistik Regresyon Sonuçları

\begin{tabular}{|c|c|c|c|c|c|c|c|c|}
\hline & $\begin{array}{l}\text { Gözlem } \\
\text { LR chi2(10) } \\
\text { Prob > chi2 } \\
\text { Pseudo R2 } \\
\text { Log likelihood }\end{array}$ & \multicolumn{2}{|c|}{$\begin{array}{cc}= & 1121 \\
= & 201,92 \\
= & 0,0000 \\
= & 0,2647 \\
= & -280,511\end{array}$} & & \multicolumn{2}{|c|}{$\begin{array}{l}\text { Gözlem } \\
\text { LR chi2(10) } \\
\text { Prob > chi2 } \\
\text { Pseudo R2 } \\
\text { Log likelihood }\end{array}$} & \multicolumn{2}{|c|}{$\begin{array}{cc}= & 1121 \\
= & 203,82 \\
= & 0,0000 \\
= & 0,2671 \\
= & -279,5640\end{array}$} \\
\hline GORUS $_{i t}$ & Coef, & Std, Err, & $z$ & VIF & Coef, & Std, Err, & $z$ & VIF \\
\hline$T E K Y_{i t}\left(m_{-} T E K Y_{i t}\right)$ & 0,7314 & 0,3989 & $1,83^{*}$ & 1,22 & 1,1508 & 0,4843 & $2,38 * *$ & 1,20 \\
\hline$I E K Y_{i t}$ & 0,7295 & 0,8906 & 0,82 & 1,12 & 0,3224 & 0,8684 & 0,37 & 1,10 \\
\hline ZMJScore $_{i t}$ & 0,3208 & 0,0587 & $5,46 * * *$ & 1,32 & 0,2609 & 0,0555 & $4,69 * * *$ & 1,30 \\
\hline DORTBUY $_{i t}$ & $-0,8464$ & 0,2688 & $-3,15^{* * *}$ & 1,35 & $-0,9133$ & 0,2709 & $-3,37 * * *$ & 1,35 \\
\hline DENETILIS & $-0,1550$ & 0,0420 & $-3,69 * * *$ & 1,02 & $-0,1590$ & 0,0420 & $-3,78 * * *$ & 1,02 \\
\hline$Z A R A R_{i t-1}$ & 0,4940 & 0,2505 & $1,97^{* *}$ & 1,28 & 0,6321 & 0,2511 & $2,52^{* *}$ & 1,27 \\
\hline$A K T I F B \cup Y_{i t}$ & $-0,1786$ & 0,1121 & $-1,59$ & 1,85 & $-0,1516$ & 0,1134 & $-1,34$ & 1,86 \\
\hline$Y A S_{i t}$ & 0,3418 & 0,2992 & 1,14 & 1,13 & 0,3955 & 0,3023 & 1,31 & 1,13 \\
\hline$K U R S A H_{i t}$ & $-1,8349$ & 0,5528 & $-3,32 * * *$ & 1,59 & $-1,8540$ & 0,5509 & $-3,37 * * *$ & 1,58 \\
\hline _cons & 1,5456 & 2,0988 & 0,74 & & 0,5383 & 2,1408 & 0,25 & \\
\hline \multirow{2}{*}{\multicolumn{2}{|c|}{$\begin{array}{c}\text { Hosmer-Lemeshow } \operatorname{chi} 2(8)= \\
\text { Prob }>\text { chi2 }=\end{array}$}} & \multicolumn{2}{|c|}{7,64} & & \multicolumn{4}{|c|}{ Hosmer-Lemeshow chi2( $(8)=13,16$} \\
\hline & & 0,46 & 590 & & & Prob > chi2 & 0,106 & \\
\hline
\end{tabular}

Tahakkuk ve işlem esaslı kâr yönetiminin bağımsız denetim görüşü üzerindeki etkisini test etmeye yönelik kurulan 1. Model'e ilişkin lojistik regresyon sonuçları Tablo 4'te verilmiştir. Tablo 4'ün sol tarafı tahakkuk esaslı kâr yönetiminin göstergesi olan ihtiyari tahakkukların işaretli değerleri ile modelin çalıştırı ması sonucu elde edilen sonuçları, tablonun sağ tarafı ise ihtiyari tahakkukların mutlak değerleri ile modelin çalıştırılması sonucu elde edilen sonuçları göstermektedir. Sol tabloda (sağ tabloda) Modelin Pseudo $\mathrm{R}^{2}$ değeri \% 26,47 (\%26,71) olup modelimiz anlamlıdır. Sol tabloda (sağ tabloda) modelin uygunluğuna ilişkin yapmış olduğumuz Hosmer-Lemeshow testi sonucu elde edilen kikare değeri 7,64 $(13,16)$ olup, anlamsızdır. Bu değer eğer \%5'in üzerinde bir değer alıyorsa model uygundur sonucuna varılmaktadır. Model uygundur. Sağ ve sol tabloda modelde bağımsız değişkenler arasında çoklu doğrusallık olup olmadığını test etmek için VIF testi yapılmıştır ve değerler düşük seviyede olduğu için bağımsız değişkenler arasında çoklu doğrusallık mevcut değildir.

Tahakkuk esaslı kâr yönetiminin göstergesi olan ihtiyari tahakkukların işaretli değerleri ile $\left(T E K Y_{i t}\right)$ ile olumlu görüş dışında görüş alma arasında pozitif $(0,7314)$ ve anlamlı $(\% 10$ seviyesinde) ilişki elde edilmiştir. Elde edilen bulgu Sengupta vd. (2007) ve Ajona vd. (2008) ile paralellik göstermektedir. Modeli mutlak değerlerle $\left(m_{-} T E K Y_{i t}\right)$ çalıştırdığında ihtiyari tahakkukların mutlak değerleri ile olumlu görüş dışında görüş alma arasında yine pozitif $(1,1508)$ anlamlı (\%5 seviyesinde) ilişki tespit edilmiştir. Elde edilen bu bulgu Butler vd. (2004) ve Bartov vd. (2001)'nin bulguları ile paralellik göstermektedir. Ihtiyari tahakkukların işaretli değerleri ile modelin çalıştırıması ile yapılan analizde sonuç olarak pozitif ve anlamlı bir ilişki tespit edilmesi işletmelerin genellikle pozitif yönlü intiyari tahakkuka başvurduklarında finansal tablolarına olumlu görüş dışında bir görüş alma olasılığının arttığını söyleyebiliriz. İhtiyari tahakkukların mutlak değerleri ile modelin çalıştırılması ile yapılan analizde sonuç olarak pozitif ve anlamlı bir ilişkinin tespit edilmesi ise yönü ne olursa olsun işletmeler ne kadar fazla ihtiyari tahakkuka başvurarak kârını yönetmişse finansal tablolarına olumlu görüş dışında bir görüş alma olasılı̆̆ı artmaktadır sonucuna varılmaktadır. Bu bağlamda "ihtiyari tahakkukların işaretli değerleri ile finansal tablolara olumlu görüş dışında görüş alma durumu arasında anlamlı bir ilişki mevcuttur" şeklinde ifade edilen $\mathrm{H}_{1 \mathrm{~A}}$ ve "ihtiyari tahakkukların mutlak değerleri ile finansal tablolara olumlu görüş dışında görüş alma durumu arasında pozitif ve anlamlı bir ilişki mevcuttur" şeklinde ifade edilen $\mathrm{H}_{1 \mathrm{~B}}$ 'yi kabul etmekteyiz. 
İşlem esaslı kâr yönetimi (IEKY $\left.{ }_{i t}\right)$ ile finansal tablolara olumlu görüş dışında görüş alma arasında pozitif $(0,7295)$ (model ihtiyari tahakkukların mutlak değerleri ile çalıştıııldığında yine pozitif 0,3224 ) fakat anlamsız ilişki mevcuttur. Elde edilen bulgular, Graham vd. (2005) ve Cohen vd. (2008)'nin iddialarını destekler niteliktedir. Yazarların da üzerinde durduğu gibi işlemlerin tasarlanarak kârın yönetilmesi muhasebeye konu olmadan gerçekleştirildiğinden dolayı bağımsız denetim firmalarının bu duruma itiraz etmesi mümkün olmayabilir. Her ne kadar işlem esaslı kâr yönetimi $\left(I E K Y_{i t}\right)$ ile olumlu görüş dışındaki görüş arasında pozitif ilişki mevcut olsa bile anlamsız bir ilişki olduğundan işletmelerin işlem esaslı kâr yönetimine başvurarak kârlarını yönetmeleri finansal tablolarına olumlu görüş dışında bir görüş alma olasılığını arttırmamaktadır. Bu bağlamda "İ̧̧lem esaslı kâr yönetimi ile finansal tablolara olumlu görüş dışında görüş alma durumu arasında anlamlı bir ilişki yoktur" şeklinde ifade edilen $\mathrm{H}_{2}$ 'yi kabul etmekteyiz.

Kontrol değişkenlerimiz olan bağımsız denetim kuruluşunun büyüklüğü (DORTBUY $\left.{ }_{i t}\right)$ ile finansal tablolara olumlu görüş dışında görüş alma arasında negatif (sol:-0,8464, sağ: -0,9133) anlamlı (sol: \%1 seviyesinde, sağ: \%1 seviyesinde) ilişkiye rastlanmıştır. Bu bağlamda işletmelerin bağımsız denetimi 4 büyük denetim firmasından biri tarafından gerçekleştirilmesi durumunda finansal tablolarına olumlu görüş dışında bir görüş alma olasılığı azalmaktadır. Böyle bir bulgunun elde edilmesinin birkaç farklı nedeni olabilir. Örneklemimizdeki 4 büyük denetim firması tarafından denetlenen ve denetlenmeyen işletmelerin sayılarına bakıldığı zaman, bağımsız denetimin $\% 55,58$ 'i 4 büyük denetim firmasından biri tarafından gerçekleştirilmektedir. 4 büyük denetim firmasının iş yoğunlukları, işletmelerin başvurmuş oldukları ihtiyari tahakkukları gözden kaçırmasına ve finansal tablolara olumlu görüş dışında görüş vermek yerine olumlu görüş vermelerine neden olabilir. Bir diğer neden ise, rekabetin yüksek olduğu bağımsız denetim piyasasında bağımsız denetim firmaları firma politikası olarak müşteri kaybetmemek adına tahakkuk esaslı kâr yönetiminin göstergesi olan ihtiyari tahakkukları tespit etmeleri ve olumlu görüş dışında bir görüş vermeleri gerektiği halde olumlu görüş vermeleri olarak açıklanabilir.

Bağımsız denetim kuruluşu ile iş ilişki süresi $\left(D E N E T I L I S_{i t}\right)$ ile finansal tablolara olumlu görüş dışında bir görüş alma durumu arasında negatif (sol:-0,1550, sağ:-0,1590) anlamlı (sol:\%1 seviyesinde, sağ:\%1 seviyesinde) ilişkiye rastlanmıştır. İşletmelerin bağımsız denetim kuruluşu ile ilişki süresi arttıkça finansal tablolarına olumlu görüş dışında bir görüş alma olasılığı azalmaktadır. Elde edilen bulgudan çıkarılan sonuç, Vanstraelen (2000)'inde savunduğu gibi iş ilişki süresinin artması denetim firması ile denetlenen işletme arasında yakınlığa neden olmakta ve oluşan yakınlıktan dolayı finansal tablolara olumlu görüş dışında bir görüş vermeleri gerektiği durumda olumlu görüş vermelerine neden olduğu yönündedir.

Geçmiş dönemde zarar açıklama durumu (ZARAR $i t-1)$ ile mevcut dönemde finansal tablolara olumlu görüş dışında görüş alma durumu arasında pozitif (sol:0,4940, sağ:0,6321) anlamlı (sol:\%5 seviyesinde, sağ:\%5 seviyesinde) ilişki tespit edilmiştir. Geçmiş dönemde zarar açıklamak finansal tablolara olumlu görüş dışında bir görüş alma olasılığını arttırmaktadır. Kurumsal sahiplik oranı $\left(K U R S A H_{i t}\right)$ ile finansal tablolara olumlu görüş dışında bir görüş alma arasında negatif (sol:-1,8349, sağ:-1,8540) anlamlı (sol:\%1 seviyesinde, sağ:\%1 seviyesinde) tespit edilmiştir. Kurumsal sahiplik oranı arttıkça finansal tablolara olumlu görüş dışında görüş alma olasılı̆ı̆ azalmaktadır. Chung ve Zhang (2011)'in da ele aldığı gibi yüksek kurumsal sahiplik durumunda bu sahipler kendilerine emanet edilen fonları kendi çıkarlarının üzerinde tuttuklarından etkin kontrol ve gözetimi sağlayarak işletmelerdeki tahakkuk esaslı kâr yönetimi uygulamalarına başvurulması konusunda kısıtlayıcı etkide bulunup, işletmelerin finansal tablolarına olumlu görüş dışında bir görüş almamaları konusunda etkin rol oynamaktadır. Zmijewski Modeli'ne (1984) göre tespit ettiğimiz işletmelerin finansal sıkıntı seviyeleri (ZMJScore ${ }_{i t}$ ) ile işletmelerin finansal tablolarına olumlu görüş dışında görüş alma durumu arasında pozitif (sol:0,3208, sağ:0,2609) anlamlı (sol:\%1 seviyesinde, sağ: \%1 seviyesinde) ilişki mevcuttur. Finansal sıkıntı düzeyi arttıkça finansal tablolara olumlu görüş dışında bir görüş alma olasılığı artmaktadır. Diğer kontrol değişkeni olan aktif büyüklük $\left(A K T I F B \cup Y_{i t}\right)$ ve işletmenin yaşı $\left(Y A S_{i t}\right)$ ile anlamlı bir ilişkiye rastlanmamıştır. 
4.2.2 Geçmiş Dönemde Finansal Tablolara Alınan Olumlu Görüş Dışındaki Bir Görüş Mevcut Dönemde Denetim Firması Değişikliğine Neden Olmakta Mıdır?

Tablo 5 'te geçmiş dönemde finansal tablolara olumlu görüş dışında bir görüş alma ile mevcut dönemde denetim firması değişikliği arasındaki ilişkiye yönelik havuzlanmış lojistik regresyon sonuçlarına yer verilmiştir.

Tablo 5. Model 2 İçin Havuzlanmış Lojistik Regresyon Sonuçları

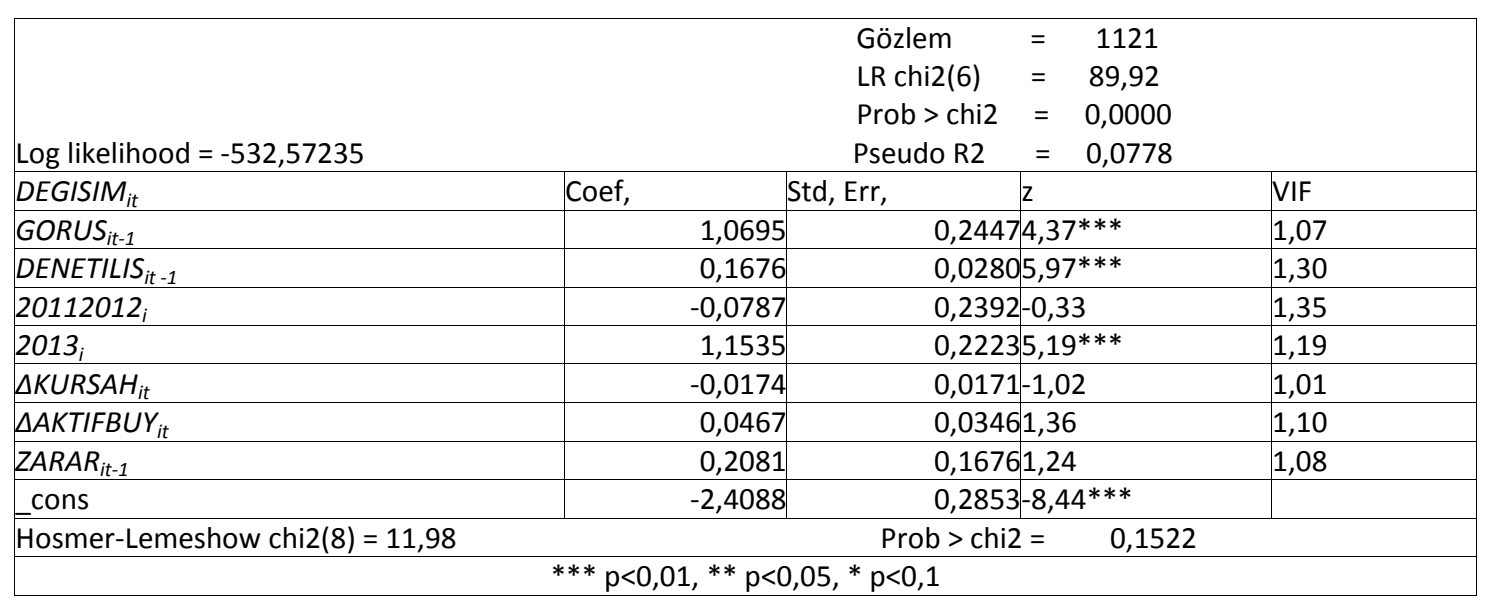

2. modelin Pseudo $R^{2}$ değeri \% 7,78 olup modelimiz anlamlıdır. Modelin uygunluğuna ilişkin yapmış olduğumuz Hosmer-Lemeshow testi sonucu elde edilen kikare değeri 11,98 olup, anlamsızdır. Model uygundur. Modelde bağımsız değişkenler arasında çoklu doğrusalllık olup olmadığının belirlenmesi için VIF testi yapılmış ve elde edilen değerlerden çoklu doğrusallığın mevcut olmadığı sonucuna varılmıştır. Geçmiş dönemde finansal tablolara olumlu görüş dışında görüş alınması $\left(G O R U S_{i t-1}\right)$ ile mevcut dönemde denetim firması değişimi arasında pozitif $(1,0695)$ ve anlamlı (\%1 seviyesinde) ilişki tespit edilmiştir. Bu bulgu ile geçmiş dönemde finansal tablolara olumlu görüş dışında bir görüş alma durumunda mevcut dönemde denetim firmasını değiştirme olasılığı artmaktadır sonucuna varılmaktadır. Bu bağlamda "Geçmiş dönemde olumlu görüş dışında bir görüş alma durumu ile mevcut dönemde denetim firması değişikliği arasında pozitif ve anlamlı ilişki vardır" şeklinde ifade edilen $\mathrm{H}_{4}$ 'ü kabul ediyoruz. Elde edilen bulgu, Lennox (2000); Davidson III vd. (2006)'nin elde etmiş olduğu bulgularla paralellik göstermektedir.

Kontrol değişkeni olarak kullanılan mevcut dönemde denetim firması değiştirmeden önceki çalıştığı denetim firması ile olan iş ilişki süresi $\left(D^{2}\right.$ NETILIS $\left._{i t-1}\right)$ ile denetim firması değişikliği arasında pozitif $(0,1676)$ ve anlamlı (\%1 seviyesinde) ilişki tespit edilmiştir. Denetim firması değişmeden önce çalışılan denetim firması ile olan iş ilişki süresi ne kadar fazla ise denetim firmasını değiştirme olasılığı o kadar artmaktadır. Böyle bir bulgu elde edilmesinin nedeni daha önce de ele alındığı gibi, geçmişte çalışılan denetim firması ile olan iş ilişki süresi arttıkça denetim firması ve işletme arasında doğacak yakınlıktan dolayı denetim firmasının bağımsızlığı tehlikeye düşmekle birlikte, işletmeler bağımsız denetim fonksiyonun etkin bir şekilde yerine getirildiğine dair işletmenin taraflarının güvenini sarsmamak adına denetim firmasını değiştirme eğiliminde olmaktadır. İlk modelde kontrol değişkeni olarak kullanılan işletmenin yaşı, işletmenin büyüklüğü ile olumlu görüş dışından bir görüş arasından anlamlı bir ilişki tespit edilememiştir.

Kontrol değişkeni olarak kullanılan $2013_{i}$ yılı değişkeni ile denetim firması değişimi arasında pozitif $(1,1535)$ ve anlamlı (\%1 seviyesinde) ilişki tespit edilmiştir. $2013_{i}$ yılında işletmeler denetim firmasını değiştirme eğilimindedir. 2013 yılında yapılan son düzenleme ile işletmeler zorunlu rotasyon uygulamasından dolayı denetim firmalarını değiştirmişlerdir. Kullanılan diğer bir yıl kontrol değişkeni olan 20112012 ${ }_{i}$ değişkeni ile denetim firması değişimi arasında anlamlı bir ilişkiye rastlanmamıştır. Bu durumun muhtemel nedeni ise, 2011 ve 2012 yıllarında rotasyona ilişkin düzenlemede bir takım koşulları yerine getiren denetim firmalarının rotasyona ilişkin düzenlemeden muaf tutulması olarak görülmektedir. 
İkinci modelde diğer kontrol değişkenlerimiz olan aktif büyüklükte meydana gelen değişim $\left(\triangle A K T I F B U Y_{i t}\right)$, kurumsal sahiplik oranında meydana gelen değişim $\left(\triangle K U R S A H_{i t}\right)$, geçmiş dönem işletmenin zarar açıklamış olması (ZARAR $R_{\text {it-1 }}$ ) değişkeni ile anlamlı ilişkiye rastlanmamıştır.

\section{Sonuç}

Bu çalışmada, tahakkuk ve işlem esaslı kâr yönetimi uygulamalarının işletmelerin finansal tablolarına aldıkları bağımsız denetim görüşü üzerinde etkisi olup olmadığı ve geçmiş dönemde finansal tablolara alınan olumlu görüş dışındaki görüşün mevcut dönemde denetim firması değişimine neden olup olmadığı kontrol değişkenleri de kullanılarak araştırılmıştır.

Bu çalışmada işletmeler, ihtiyari tahakkuklara başvurarak kârlarını tahakkuk esaslı yönetmeleri durumunda olumlu görüş dışında görüş alma olasılıkları artmaktadır sonucuna varılmaktadır. Elde edilen sonuç, ihtiyari tahakkukların hem işaretli değerlerinin hem de mutlak değerlerinin ilgili modelde kullanılması sonucunda farklılık göstermemektedir. Daha açık bir ifade ile işletmeler ne kadar fazla ihtiyari tahakkuka başvurmuşsa veya işletmeler en dip noktayı aşağı veya yukarı doğru yönetme eğiliminden hangisini tercih etmiş olsalar bile finansal tablolarına olumlu dışında bir görüş alma olasılıkları artmaktadır. Bu bulgu Butler, Leone ve Willenborg (2004), Bartov, Gul ve Tsui (2000), Sengupta ve Shen (2007), Shivakumar (1996)'ın elde etmiş olduğu bulgularla paralellik göstermektedir. İşletmelerin tahakkuk esaslı kâr yönetimine başvurmaları durumunda finansal tablolarına olumlu görüş dışında bir görüş verilme olasılığı artmaktadır. Diğer bir ifadeyle bu durum, denetim firmalarının ihtiyari tahakkukları tespit ederek işletmelerin finansal tablolarına olumlu görüş dışında bir görüş vermesine neden olmaktadır. Bu çalışmadan elde edilen diğer bulgu işletmelerin işlem esaslı kârı yönetmeleri durumunda finansal tablolarına olumlu görüş dışında bir görüş alma olasılıkları artmamaktadır sonucuna varılmaktadır. Çünkü işlem esaslı kâr yönetimi doğrudan finansal tablolarda değil finansal tablolara konu olan ekonomik olaylarda gerçekleştirilmektedir. Daha açık bir ifade ile işlemler finansal tablolara konu olmadan yönetiliyorsa ve yönetilen bir işlem genel kabul görmüş muhasebe ilkeleri, standartlar veya yasal düzenlemeler çerçevesinde finansal tablolarda sunulup amacı doğrultusunda kârlıı̆̆ı etkiliyorsa, bu işlemin bağımsız denetçiler açısından bir bağlayıcılığı olmamakta ve bağımsız denetçiler tarafından yapılan değerlendirmeler sonucu verilecek olan bağımsız denetim görüşünde önemli bir etkisi olmamaktadır. Başka bir açıdan ele aldığımızda Cohen vd. (2008) ve Graham vd. (2005)'ın ele aldığı gibi bu tür kâr yönetimi uygulamaları finansal tablolara konu olmadan gerçekleştirildiğinden dolayı denetim firmalarının gözünden kaçmakta ve tespit edilememekte ve böylelikle finansal tablolar hakkında olumlu görüş dışında bir görüş verme olasılığı azalmaktadır.

$\mathrm{Bu}$ çalışmada, ilk modelde kontrol değişkeni olarak işletmelerin finansal sıkıntı seviyeleri kullanılmıştır. İşletmelerin finansal sıkıntı içinde olması onların sürekliliklerini tehlikeye düşürdüğünden denetim firmaları bu işletmelerin finansal tablolarına olumlu görüş dışında bir görüş verdiği elde edilen bulgular doğrultusunda söylenebilir. Ayrıca ilk modelde kontrol değişkeni olarak kullandığımız denetim firmasının büyüklüğü, denetim firması ile iş ilişkisi süresi, geçmiş dönemde zarar açıklama, kurumsal sahiplik oranına ilişkin bulgulara da rastlanmaktadır. Denetim firmasının 4 büyük denetim firmasından biri olması durumunda ve işletmelerin çalıştıkları denetim firması ile iş ilişki süresi arttıkça ortaya çıkan yakınlıktan dolayı finansal tablolarına olumlu görüş dışında bir görüş alma olasılıkları azalmaktadır sonucuna elde edilen bulgulardan yola çıkılarak varılmaktadır. Ayrıca, geçmiş dönemde zarar açıklama durumu ile mevcut dönemde finansal tablolara olumlu görüş dışında bir görüş alma durumu arasında pozitif anlamlı ilişki tespit edilirken, kurumsal sahiplik oranı ile finansal tablolara olumlu görüş dışında bir görüş alma durumu arasında negatif anlamlı ilişki tespit edilmiştir.

Bu çalışmada, ikinci modelin sonuçlarına göre işletmeler, geçmiş dönemde finansal tablolarına olumlu görüş dışında bir görüş almışsa denetim firmasını değiştirme eğiliminde olmaktadır. Ayrıca ikinci modelde kontrol değişkeni olarak kullandığımız değişkenleri ele aldığımız zaman, denetim firması değiştirmeden önce çalıştığı denetim firması ile olan iş ilişki süresi arttıkça denetim firması değiştirme eğiliminde olduğu sonucu elde edilmiştir. Ayrıca 2013 yılında yapılan düzenlemenin işletmeleri denetim firmasını değiştirmeye zorladığını söyleyebiliriz. 
Çalışma, denetim firması değişiminden önce ve sonra işletmelerin tahakkuk ve işlem esaslı kâr yönetimi uygulamalarının ne yönde olduğu, büyük denetim firmalarından küçük denetim firmalarına, küçük denetim firmalarından büyük denetim firmalarına veya aynı klasmanda yer alan denetim firmaları arasındaki değişimin nedenlerinin ne olduğu yönünde farklı değişkenler eklenerek de geliştirilebilir.

\section{Son Notlar}

${ }^{1} T_{i t}=\left(\Delta D V_{i t}-\Delta N V B V_{i t}\right)-\left(\Delta K V Y K_{i t}-\Delta U V V A T F_{i t}-\Delta O V Y K_{i t}\right)-A I P_{i t}$ Açılamasl; $T T_{i t} i$ işletmesinin $t$ zamandaki toplam tahakkukları, $\triangle D V_{i t}=i$ işletmesinin $t$ zamanda dönen varlıklarındaki değiş̧im, $\triangle N V B V_{i t}=i$ işletmesinin $t$ zamanda nakit ve nakit benzeri varlıklarındaki değişim, $\triangle K V Y K_{i t}=i$ işletmesinin $t$ zamanda kısa vadeli yabancı kaynaklarında meydana gelen değişim, $\triangle U V V A T F_{i t}=i$ işletmesinin $t$ zamanda uzun vadeli borçlarının anapara taksit ve faizlerindeki değişim, $\Delta O V Y K_{i t}=i$ işletmesinin $t$ zamanda ödenecek vergi ve yükümlülük karşılıklarındaki değiş̧im, $A I P_{i t}=i$ işletmesinin $t$ zamanda amortisman ve itfa payları.

\section{Kaynaklar}

Acar, G. (2011). Application of discretionary accruals models for detecting earnings management in Istanbul Stock Exchange. Marmara Üniversitesi Sosyal Bilimler Enstitüsü, Yayınlanmamış Doktora Tezi.

Adıgüzel, H. (2012). The effect of internal corporate governance structure to the earnings management practice in Turkey. Marmara Üniversitesi Sosyal Bilimler Enstitüsü, Yayınlanmamış Doktora Tezi.

Ajona, L.A., \& Dallo, F.L. \&Alegría, S.S. (2008). Discretionary accruals and auditor behaviour in code-law contexts: an application to failing Spanish firms. European Accounting Review, 17(4), 641-666.

Aren, S. (2003). Yöneticilerin kar yönetimi ile ilgili tutumları ve imkb'de bir uygulama. Gebze Yüksek Teknoloji Enstitüsü Sosyal Bilimler Enstitüsü, Yayınlanmamış Doktora Tezi.

Arioğlu, E., \& Tuan K. (2015). Auditor rotation at Borsa İstanbul firms: an event study, Journal of Economics Accounting and Finance, 2(3), 397-408.

Ayarlığlu, M.A. (2007). Kar yönetimi uygulamaları ve Istanbul Menkul Kıymetler Borsası'nda test edilmesi, Hacettepe Üniversitesi Sosyal Bilimler Enstitüsü, Yayınlanmamış Doktora Tezi.

Bartov, E., Gul, F. A., \& Tsui, J.S.L. (2001). Discretionary-Accruals models and audit qualifications. Journal of Accounting and Economics, 30(3), 421-452.

Boone, J.P. \& Khurana, I.K. \& Raman, K.K. (2010). Do the big 4 and the second-tier firms provide audits of similar quality?. Journal of Accounting and Public Policy, 29(4), 330-352.

Butler, M., Leone, A.J., \& Willenborg, M. (2004). An empirical analysis of auditor reporting and its association with abnormal accruals. Journal of Accounting and Economics, 37(2), 139-165.

Carey, P., \& Simnett, R. (2006). Audit partner tenure and audit quality. The Accounting Review, 81(3), 653-676.

Chan, K.H., Lin, K.Z., \& Mo, P.L. (2006). A political-economic analysis of auditor reporting and auditor switches. Review of Accounting Studies, 11(1), 21-48.

Chan, K.H., Lin, K.Z., \& Wong, B. (2010). The impact of government ownership and institutions on the reporting behavior of local auditors in China. Journal of International Accounting Research, 9(2), 1-20.

Chen, C.J.P. \& Chen, S., \& Su, X. (2001). Profitability regulation, earnings management, and modified audit opinions: evidence from China. Auditing: A Journal of Practice and Theory, 20(2), 9-30.

Chi, W., Lisic, L.L., \& Pevzner, M. (2011). Is enhanged audit quality associated with greater real earnings management?. Accounting Horizons, 25(2), 315-335.

Chow, C.W., \& Rice, S.J. (1982). Qualified audit opinions and audit switching. The Accounting Review, LVII (2), 326-335.

Chung, K.H., \& Zhang, H. (2011). Corporate governance and institutional ownership. Journal of Financial and Quantitative Analysis, 46(1), 247-273.

Cohen, D.A., Dey, A., \& Lys, T.Z. (2008). Real and accrual-based earnings management in the pre- and post-sarbanesoxley periods. The Accounting Review, 83(3),757-787.

Cohen, D.A,. \& Zarowin, P. (2010). Accrual-based and real earnings management activities around seasoned equity offering. Journal of Accounting and Economics, 50(1), 2-19. 
Craswell, A.T. (1988). The association between qualified opinions and audit switches. Accounting and Business Research, 19(73), 23-31.

Curuk, T., \& Yasar, A. (2014). The association between earnings management and auditor reporting: evidence from Turkish Stock Market. Journal of Academic Research, 6(3), 53-64.

Davidson III, W.N., Jiraporn, P. \& DaDalt, P. (2006). Causes and consequences of audit shopping: an analysis of auditor opinions, earnings management, and auditor changes. Quarterly Journal of Business and Economics, 45(1-2), 69-87.

Davis, L.R., So,B., \&Trompeter, G.(2000). Auditor tenure, auditor independence and earnings management, Boston College Working Paper, 1-42.

DeAngelo, L.E. (1981). Auditor size and audit quality. Journal of Accounting and Economics, 3(3), 183-199.

DeFond, M.L., Wong, T.J., \& Li, S. (2000). The impact of improved auditor independence on audit market concentration in China. Journal of Accounting and Economics, 28(3), 269-305.

Dechow, P.M., Sloan, R.G., \& Sweeney, A.P. (1995). Detecting earnings management. The Accounting Review, 70(2), 193-225.

Dopuch, N., Holthausen, R.W., \& Leftwich, R.W. (1986). Predicting audit qualifications with financial and market variables. The Accounting Review, LXII(3), 431-454.

Durak, M.G. (2010). Türkiye'de uluslararası finansal raporlama standartlarına geçişin tahakkukların güvenilirliği ve kazançların süreğenliği üzerindeki etkileri: Istanbul Menkul Kıymetler Borsası (iMKB) uygulamaları. Dokuz Eylül Üniversitesi, Sosyal Bilimler Enstitüsü, Yayınlanmamış Doktora Tezi.

Ertan, Y .(2011). Türkiye muhasebe standartlarının denetim ve muhasebe kalitesine etkisi: bir uygulama. Uludağ Üniversitesi Sosyal Bilimler Enstitüsü, Yayınlanmamış Doktora Tezi.

Francis, J.R., \& Yu, M.D. (2009). Big 4 office size and audit quality. The Accounting Review, 84(5), 1521-1552.

Gajevzsky, A. (2014). The Impact of auditor's opinion on earnings management: evidence from romania. Network Intelligence Studies, II(1(3)), 61-73.

Ge, W., \& Kim V. J.B.B. (2014). Boards, takeover protection and real earnings management. Review of Quantitative Finance and Accounting, 43(4), 651-682.

Geiger, M.A., \& Rama, D.V.(2006). Audit firm size and going-concern reporting accuracy. Accounting Horizons, 20(1), 1-17.

Graham, J.R., Harvey, C.R., \& Rajgopal, S. (2005). The economic implications of corporate financial reporting. Journal of Accounting and Economics, 40(1-3), 3-73.

Han, S., Kang, T., \& Rees, L. (2013). The association between institutional ownership and audit properties. Asia-Pacific Journal of Accounting and Economics, 20(2) 199-222.

Herbohn, K., \& Ragunathan, V. (2008). Auditor reporting and earnings management: some additional evidence. Accounting and Finance, 48(4), 575-601.

Herrmann, D., Inoue, T., \& Thomas, W.B. (2003). The sales of assets to manage earnings in Japan. Journal of Accounting Research, 41(1), 89-108.

Hudaib, M., \& Cooke, T.E. (2005). The impact of managing director changes and financial distress on audit qualifications and auditor switching. Journal of Business Finance and Accounting, 32(9)\&(10), 1703-1739.

Jackson, S.B., \& Wilcox, W.E. (2000). Do managers grand sales price reductions to avoid losses and declines in earnings and sales?. QJBI, 39(4), 3-20.

Jones, J.J. (1991). Earnings management during import relief investigations. Journal of Accounting Research, 29(2), 193-228.

Jiambalvo, J., Rajgopal, S. \& Venkatachalam, M. (2002). Institutional ownership and the extent to which stock prices reflect future earnings. Contemporary Accounting Research, 19(1), 117-145.

Karabayır, M.E. (2012). Uluslararası finansal raporlama standartları ve muhasebe kalitesi: iMKB örneği. Ankara Üniversitesi, Sosyal Bilimler Enstitüsü, Yayınlanmamış Doktora Tezi.

Kabadayı, N. (2010). Kazanç yönetimi konusunda etik değer anlayışının araştırılması. Selçuk Üniversitesi Sosyal Bilimler Enstitüsü, Yayınlanmamış Yüksek Lisans Tezi.

Kamu Gözetimi Muhasebe ve Denetim Standartları Kurumu, BDS 200: Bağımsız Denetçinin Genel Amaçları ve Bağımsız Denetimin Bağımsız Denetim Standartlarına Uygun Olarak Yürütülmesi. http://www.kgk.gov.tr/contents/files/BDS/BDS_200.pdf (Erişim Tarihi: 20.09.2015). 
Kamu Gözetimi Muhasebe ve Denetim Standartları Kurumu. BDS 700: Finansal Tablolara Ilişkin Görüş Oluşturma ve Raporlama. http://www.kgk.gov.tr/contents/files/BDS/BDS_700_Resmi_Gazete.pdf, (Erişim Tarihi: 15.09.2015).

Kamu Gözetimi Muhasebe ve Denetim Standartları Kurumu. BDS 705: Bağımsız Denetçi Raporunda Olumlu Görüş Dışında Bir Görüş Verilmesi. http://www.kgk.gov.tr/contents/files/BDS/BDS_705_Resmi_Gazete.pdf, (Erişim Tarihi: 15.09.2015).

Kang, S., \& Kim, Y. (2012). The Effect of corporate governance on real activity-based earnings management. Journal of Business Economics and Management, 13(1), 29-52.

Karacaer, S., \& Özek, P. (2010). Denetim firması büyüklüğü ve kar yönetimi ilişkisi: İMKB şirketleri üzerine ampirik bir çalışma. Muhasebe ve Finansman Dergisi, 48, 60-74.

Karaibrahimoğlu, Y. (2010). The role of corporate governance on earnings management: quarterly evidence from Turkey. İzmir Ekonomi Üniversitesi Sosyal Bilimler Enstitüsü, Yayınlanmamış Doktora Tezi.

Kazsnik, R. (1999). On the association between voluntary disclosure and earnings management, Journal of Accounting Reseach, 37(1), 57-81.

Kothari, S.P.\& Leone,A.J.\& Wasley,C.E. (2005). Performance matched discreationary accruals measures. Journal of Accounting and Economics, 39(1), 163-197.

Lennox, C. (2000). Do companies successfully engage in opinion-shopping? evidence from the UK. Journal of Accounting and Economics, 29(3), 321-337.

Monroe, G.S. \& Teh, S.T. (1993). Predicting uncertainty audit qualifications in australia using publicly available information. Accounting and Finance, 33(2), 79-106.

Nasser, A.T.A., Wahid, E.A., Nazri, S.N.F.S.M., \& Hudaib, M.(2006). Auditor-client relationship: the case of audit tenure and auditor switching in Malaysia. Managerial Auditing Journal, 21(7), 724-737.

Roychowdhury, S. (2006). Earnings management through real activities manipulation. Journal of Accounting and Economics, 42(3), 335-370.

Ocak, M. (2013). Kurumsal yönetişim bileşenlerinin tahakkuk ve işlem esaslı kar yönetimi üzerine etkileri: bir uygulama. İstanbul Üniversitesi, Sosyal Bilimler Enstitüsü, Yayınlanmamış Doktora Tezi.

Omid, A.M. (2015), Qualified audit opinion, accounting earnings management and real earnings management, Asian Economics and Financial Review, 5(1), 46-57.

Önder, Ş. (2012). İşletmelerin kar yönetimi uygulamalarında kurumsal yönetim yapılarının etkisi: iMKB üzerine bir uygulama, Dumlupınar Üniversitesi Sosyal Bilimler Enstitüsü, Yayınlanmamış Doktora Tezi.

Özden, V.E.A. (2013). Uluslararası finansal raporlama standartlarının kar yönetimine etkisi: bağımsız denetçilerin algıları üzerine bir araştırma. Marmara Üniversitesi Sosyal Bilimler Enstitüsü, Yayınlanmamış Doktora Tezi.

Özcan, M. (2007). Kar yönetimi uygulamalarına ilişkin etik yargı farklılıkları. Gebze Yüksek Teknoloji Enstitüsü Sosyal Bilimler Enstitüsü, Yayınlanmamış Doktora Tezi.

Salleh, K., \& Jasmani, H.(2014). Audit rotation and audit report: empirical evidence from Malaysian PLCs over the reriod of ten years, Procedia-Social and Behavioral Sciences, 145, 40-50.

Sengupta, P., \& Shen. M. (2007). Can accruals quality explain auditors' decision making? the impact of accruals quality on audit fees, going concern opinions and auditor change. Working Paper Series, 2007, http://papers.ssrn.com/sol3/papers.cfm?abstract_id=1178282. (Erişim Tarihi: 18.06.2015)

Sermaye Piyasası Kurulu (2010). Yatırıma Bilgilendirme Kitapçıkları 3, Yatırım Fonları. http://www.spk.gov.tr/displayfile.aspx?action=displayfile\&pageid=78\&fn=78.pdf\&submenuheader=null, (Erişim Tarihi: 20.01.2016).

Shivakumar, L. (1996). Estimating abnormal accruals for detection of earnings management. Working Paper Series, Vanderbilt University.

SPK, Seri X, No:25: Sermaye Piyasasında Bağımsız Denetim Standartları Hakkında Tebliğde Değişiklik Yapılmasına Dair Tebliğ.

Tsipouridou, M., \& Spathis, C. (2014). Audit opinion and earnings management. Accounting Forum, 38(1), 38-54.

Vanstraelen, A. (2000). Impact of renewable long-term audit mandates on audit quality. The European Accounting Review, 9(3), 419-442.

Vanstraelen, A. (2003). Going-concern opinions, auditor switching, and the self-fulfilling prophecy effect examined in the regulatory context of Belgium. Journal of Accounting, Auditing and Finance, 18(2), 231-253. 
Varan, S. (2012). The Impact of ownership structure on earnings management through available for sale securities: an assessment of IAS 39 in Turkish banking industry. Dokuz Eylül Üniversitesi Sosyal Bilimler Enstitüsü, Yayınlanmamış Doktora Tezi.

Visvanatha, G. (2008). Corporate governance and real earnings management. Accounting and Financial Studies Journal. 12(1), 9-22.

Yaşar, A. (2011). Bağımsız dış denetim kalitesinin kar yönetimi üzerine etkisi: iMKB'de kayıtlı işletmeler üzerine bir uygulama. Çukurova Üniversitesi Sosyal Bilimler Enstitüsü, Yayınlanmamış Doktora Tezi.

Yaşar, A. (2015). Olumsuz denetim görüşü, bağımsız denetçi değişikliği arasındaki ilişki: Borsa İstanbul sanayi şirketleri üzerine bir uygulama, Muhasebe ve Finansman Dergisi, 65, 81-96.

Yükseltürk, O. (2006). İşletmelerde kârı yüksek gösterme yöntemleri ve Türkiye'de hisse senetlerinin halka arzı öncesi kârı yüksek gösterme eğilimleri. İstanbul Üniversitesi Sosyal Bilimler Enstitüsü, Yayınlanmamış Doktora Tezi.

Zmijewski, M.E. (1984). Methodological issues related to the estimation of financial distress prediction models. Journal of Accounting Research, 22, 59-82.

6102 Sayılı Türk Ticaret Kanunu, Madde 400. 